\title{
Synthesis and reactivity of metal carbene complexes with heterobiaryl spacer substituents $\dagger$
}

\author{
Simon Lotz, ${ }^{* a}$ Chantelle Crause, ${ }^{a}$ Andrew J. Olivier, ${ }^{a}$ David C. Liles, ${ }^{a}$ Helmar Görls, ${ }^{b}$ Marilé Landman ${ }^{a}$ and \\ Daniela I. Bezuidenhout ${ }^{a}$
}

Received 22nd July 2008, Accepted 10th October 2008

First published as an Advance Article on the web 24th November 2008

DOI: 10.1039/b811762d

Mono- and binuclear Fischer carbene complexes, $\left[\mathrm{M}(\mathrm{CO})_{5}\{\mathrm{C}(\mathrm{OR}) \mathrm{Ar}-\mathrm{ArX}\}\right], \mathrm{X}=\mathrm{H}$, $\left\{\mathrm{C}(\mathrm{OR}) \mathrm{M}^{\prime}(\mathrm{CO})_{5}\right\} ; \mathrm{M}, \mathrm{M}^{\prime}=\mathrm{W}$ or $\mathrm{Cr} ; \mathrm{R}=\mathrm{Me}$, Et or $\left(\mathrm{CH}_{2}\right)_{4} \mathrm{OMe} ; \mathrm{Ar}=$ thiophene, N-methylpyrrole or furan units 1-20, were synthesized. For this purpose, mono-, bi- or stepwise lithiated bithiophene, $\mathrm{N}, \mathrm{N}^{\prime}$-dimethylbipyrrole, thienylfuran and $\mathrm{N}$-methyl(thienyl)pyrrole were reacted with chromium and tungsten hexacarbonyl precursors. Dilithiation in the 2- and 9-positions of N-methyl(thienyl)pyrrole could not be achieved. Alkylation of acyl metallates with triethyloxonium tetrafluoroborate or methyl trifluoromethanesulfonate in THF afforded not only the expected carbene complexes with ethoxy or methoxy substituents, but in the case of bithiophene with methyl trifluoromethanesulfonate, carbene complexes with alkoxy substituents incorporating a ring-opened tetrahydrofuran moiety. X-Ray crystallographic structure determinations were performed on $\left[\mathrm{W}(\mathrm{CO})_{5}\{\mathrm{C}(\mathrm{OMe})(\right.$ thienylfuran $\left.)\}\right](\mathbf{1 4})$, $\left[\mathrm{W}(\mathrm{CO})_{5}\{\mathrm{C}(\mathrm{OMe})(\mathrm{N}\right.$-methylthienylpyrrole $\left.)\}\right](\mathbf{2 0})$ and $\left[\left\{\mathrm{W}(\mathrm{CO})_{5}\right\}_{2}\left\{\mu-\mathrm{C}(\mathrm{OEt})\left(\mathrm{N}, \mathrm{N}^{\prime}-\right.\right.\right.$ dimethylbipyrrolylC(OEt)\}] (12) to assess the role of the heterobiaryl substituent on the structural features of the carbene ligand in the complexes. Complexes $\left[\left\{\mathrm{Cr}(\mathrm{CO})_{5}\right\}_{2}\{\mu-\mathrm{C}(\mathrm{OMe})\right.$ bithienylC $\left.(\mathrm{OEt})\}\right]$ (3), $\left[(\mathrm{CO})_{5} \mathrm{Cr}\{\mu-\mathrm{C}(\mathrm{OMe})\right.$ bithienylC $\left.(\mathrm{OMe})\} \mathrm{W}(\mathrm{CO})_{5}\right](\mathbf{5})$ and $\left[\left\{\mathrm{Cr}(\mathrm{CO})_{5}\right\}_{2}\{\mu-\mathrm{C}(\mathrm{OMe})\right.$ thienylfuranC$(\mathrm{OMe})\}]$ (15) were reacted with 3-hexyne to study their behaviour in benzannulation reactions. The major products generated by the biscarbene complexes were regio-selectively determined by the nature of the metal site and that of the heteroatom in the arene rings. The monocarbene complexes $\left[\mathrm{Cr}(\mathrm{CO})_{5}\{\mathrm{C}(\mathrm{OMe})\right.$ thienylfuran $](\mathbf{1 3})$ and $\left[\mathrm{Cr}(\mathrm{CO})_{5}\{\mathrm{C}(\mathrm{OEt})(\mathrm{N}\right.$-methylthienylpyrrole $\left.)\}\right](\mathbf{1 9})$ were refluxed in THF for 2 hours in the presence of $\left[\mathrm{Pd}\left(\mathrm{PPh}_{4}\right)_{4}\right]$ to afforded the carbene-carbene coupled olefinic products and small amounts of the corresponding 2-ethyl(biheteroaryl)acetate. By contrast, the biscarbene complex of thienylfuran (15), afforded only the 2,9-diester of thienylfuran.

\section{Introduction}

Heteroaromatic five membered rings, linked at the $\alpha$-carbon atoms, form $\pi$-conjugated chain structures and can facilitate charge transfer or electron delocalization from one end of the molecule through the backbone to the opposite end. ${ }^{1}$ For effective $\pi$-conjugation coplanarity of the rings must be retained. In view of the many applications of heterobiaryls, a number of catalytic methods have been developed to prepare biaryl heterocycles of thiophene, furan and pyrrole from monoheteroaryl precursors and invariably proceed using either nickel or palladium catalysts. ${ }^{2}$ Some of the most commonly used catalytic methods are the Kharasch, ${ }^{3}$ Negishi, ${ }^{4}$ Stille $^{5}$ and Suzuki ${ }^{6}$ coupling reactions. These catalytic routes enable the facile preparation of both symmetrical and asymmetrical heterobiaryls in cross-coupling reactions. Although some non-catalytic methods have also been used (photochemical, ${ }^{7}$ direct coupling, ${ }^{8}$ cyclization, ${ }^{9}$ etc. reactions) the catalytic cross-coupling methodology is the method of

${ }^{a}$ Department of Chemistry, University of Pretoria, Pretoria 0002, South Africa.E-mail: simon.lotz@up.ac.za; Fax: +27 (0) 124204687

${ }^{b}$ Friedrich-Schiller-Universität, Institut für Anorganische und Analytische Chemie, Lessingstrasse 8, Jena 07743, Germany

$\dagger$ CCDC reference numbers 686736-686738. For crystallographic data in CIF or other electronic format see DOI: $10.1039 / \mathrm{b} 811762 \mathrm{~d}$ choice in our laboratories when starting from monoheteroaryl precursors and adaptations were made from the published methods. ${ }^{10}$

The attachment of two different transition metal fragments at the termini of a linear, planar and conjugated heteroarene spacer will create two different electronic and chemical poles in the molecule. Maiorana and co-workers ${ }^{11}$ prepared the first Fischer mixed-metal biscarbene complex of bithiophene to study potential non-linear optical properties of such complexes. Progress in this area of research has been hampered by limited methods of synthesis. Phenyl, acetylene and ethene units are more commonly found in conjugated bridging ligands, but are often not very stable compared to heteraromatic moieties. ${ }^{12}$

Heteroarene substrates are readily deprotonated at the $\alpha-$ position, using the strong base $n$-BuLi. ${ }^{13}$ The resulting heteroaryl nucleophiles can attack carbonyl ligands of transition metal carbonyl precursors and after subsequent alkylation afford Fischer metal carbene complexes. ${ }^{14}$ It is also possible to prepare biscarbene complexes with metal fragments on both sides of the heteroarene spacer from bimetallated substrates, creating an electronic pathway for potential metal-metal communication. ${ }^{15}$ Carbon atoms in Fischer carbene complexes are highly reactive electrophilic centres which are stabilized by electron donating substituents. ${ }^{16}$ The transfer of electron density from an electron rich heteroarene 
substituent to the carbene carbon atom can contribute to the stabilization of the carbene ligand. ${ }^{17}$

Since the properties of condensed ring heteroarene carbene complexes have been explored in our laboratories, ${ }^{18}$ a study of the analogous 2,2'-heterobiaryl substrates was undertaken.

A systematic comparison of the four different biaryl heterocycles S1, S2, S3 and S4, shown in Fig. 1, on the conditions of metallation as well as application in Fischer carbene synthesis was investigated. The atom numbering shown in Fig. 1 is unconventional, but represents the labels used in this study for the reported complexes. The method used for carbene synthesis was determined by the deprotonation step of the substrates. To facilitate 2- or 2,9-deprotonation of the pyrrole substrates it was required to replace the hydrogen atom attached to the nitrogen of the ring with a methyl group.

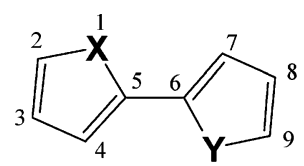

S1: $X=S, Y=S, \quad$ S2: $X=N M e, Y=N M e$, S3: $X=S, Y=O, \quad S 4: X=S, Y=N M e$

Fig. 1 Linear biaryl heterocycles (S1-S4).

In this article the synthesis of mononuclear carbene complexes with electron rich heteroaromatic substituents and binuclear biscarbene complexes with bridging heteroarene spacer units is reported. A synthetic method was devised to synthesize biscarbene complexes containing different metal fragments at the termini of the conjugated bridging heteroarene ligand. The structural features of complexes were studied in the solid state by crystal structure determinations and in solution by NMR spectroscopy. The role of the heteroatoms in the rings to affect electron delocalization and influence chemical transformations in carbene complexes was investigated.

\section{Results and discussion}

\section{Synthesis of heterobiaryl precursors (S1-S4)}

Bithiophene (S1) is commercially available. A high yield synthesis (>90\%) from thiophene, BuLi, $\mathrm{ZnI} 2, \mathrm{NCS}$ and $\mathrm{Pd}\left(\mathrm{PPh}_{3}\right)_{4}$ as the catalyst has been reported recently for bithiophene. ${ }^{19}$

2,2'-N,N'-Dimethylbipyrrole (S2) was synthesized by an oxidative coupling reaction between 2-lithio-N-methylpyrrole and $\mathrm{N}$ methylpyrrole in the presence of anhydrous nickel(II) chloride.

2,2'-Thienylfuran (S3) was prepared from 2-tributylstannylfuran and 2-bromothiophene via the Stille reaction. The tin precursor was prepared quantitatively from 2-lithiofuran by following the literature procedure. ${ }^{20}$ The $\mathrm{Pd}\left(\mathrm{PPh}_{3}\right)_{4}$-catalysed reaction between the tin precursor and a 50\% molar excess of 2-bromothiophene proceeded smoothly to afford $\mathbf{S 3}$ as a rose coloured oil in a $67 \%$ isolated yield. This compound was stored below $0{ }^{\circ} \mathrm{C}$ and under an inert atmosphere since it was found to gradually darken over time at room temperature due to decomposition.

The Negishi cross-coupling reaction was employed to prepare N-methyl-2-(2'-thienyl)pyrrole (S4) from 2-(N-methylpyrrolyl)- zinc chloride and 2-bromothiophene in the presence of the palladium(II)chloride-1,1'-bis(diphenylphosphino)ferrocene catalyst. ${ }^{21}$ This reaction was not optimized and since significant quantities of unreacted 2-bromothiophene were detected the yield could be improved by employing longer reaction times. Wynberg and co-workers ${ }^{22}$ reported that thienylfuran derivatives are sensitive to light, heat and moisture and observed darkening of the compounds after a few days even while stored at $-20{ }^{\circ} \mathrm{C}$ under nitrogen and in the dark.

\section{Metallation studies}

Monometallation studies of heterocyclic substrates have provided a general rule of oxygen and sulfur $>$ nitrogen (N-substituted nitrogen arene compounds). Thus lithiation $\alpha$ to sulfur is favoured and occurs at low temperatures in THF, whereas more stringent conditions are needed to deprotonate the position $\alpha$ to nitrogen in a N-substituted pyrrole moiety. It is known that in competitive reactions between furan and thiophene for an insufficient quantity of $n$-BuLi, furan reacts more rapidly in hexane than thiophene. ${ }^{23}$ On the other hand, thiophene reacts more rapidly than furan under reaction conditions that favour the ionisation of the $\mathrm{C}-\mathrm{Li}$ bonds (THF, etc.). ${ }^{24}$ However, in both cases the lithiation occurs in the $\alpha$-position of such heterocycles. Bithiophene (S1) was readily dimetallated in THF at $-20{ }^{\circ} \mathrm{C}$ with two equivalents of $n$-BuLi. This becomes more difficult for the deprotonation of $\mathbf{S 2}$, because $n$-BuLi attacks THF at temperatures above $0{ }^{\circ} \mathrm{C}$. Hence hexane is the solvent of choice to access higher temperatures for lithiation and TMEDA is employed as co-catalyst for the 2,9-dilithiation of $\mathrm{N}, \mathrm{N}^{\prime}$-dimethylbipyrrole. S3 was mono-lithiated under conditions that would favour deprotonation, $\alpha$ to the sulfur atom (the first lithiation was achieved at $-20{ }^{\circ} \mathrm{C}$ ) and deprotonated with a second equivalent of $n$ - $\mathrm{BuLi}$ on the furan ring, again $\alpha$ to the oxygen atom, to afford the 2,9-dilithiated thienylfuran precursor. $\mathbf{S 4}$ is readily monolithiated in THF at low temperatures on the thiophene ring, but higher temperatures required for deprotonating on the $\mathrm{N}$ methylpyrrole ring lead to decomposition and inter-ring bond cleaving.

\section{Synthesis of carbene complexes}

The monocarbene and dimetal biscarbene complexes (Table 1, list of complexes) were prepared according to Scheme 1. The monocarbene complexes can be synthesized in high yields (above $60 \%$ ) after monolithiation of the substrates. However, in this study they were isolated as by-products ( $c a .20 \%$ ) from the reaction mixture of the dilithiated substrates and metal carbonyls. Their formation can be ascribed to incomplete dimetallation of the heterobiaryl precursors. In solution, the biscarbene complexes decompose over time but can be stored for longer periods under

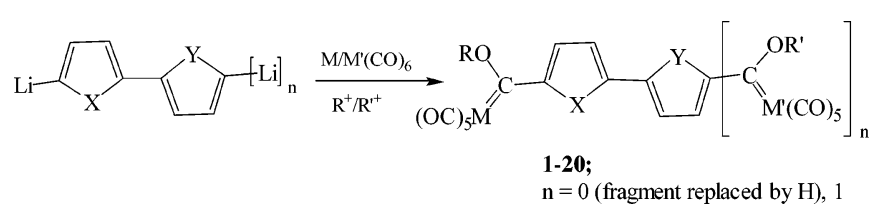

Scheme 1 General procedure for the synthesis of the carbene complexes 1-20. 
Table 1 List of complexes

\begin{tabular}{|c|c|c|c|c|c|c|}
\hline \multirow[t]{7}{*}{$\mathrm{X}=\mathrm{S}, \mathrm{Y}=\mathrm{S}$} & $n=0$ & $\begin{array}{l}\mathrm{M}=\mathrm{Cr} \\
\mathrm{M}=\mathrm{W}\end{array}$ & & $\begin{array}{l}\mathrm{R}=\mathrm{Me} \\
\mathrm{R}=\mathrm{Me}\end{array}$ & & 1 \\
\hline & $n=1$ & $\mathrm{M}=\mathrm{Cr}$ & $\mathrm{M}^{\prime}=\mathrm{Cr}$ & $\mathrm{R}=\mathrm{Me}$ & $\mathrm{R}^{\prime}=\mathrm{Me}$ & 3 \\
\hline & & $\mathrm{M}=\mathrm{W}$ & $\mathrm{M}^{\prime}=\mathrm{W}$ & $\mathrm{R}=\mathrm{Me}$ & $\mathrm{R}^{\prime}=\mathrm{Me}$ & 4 \\
\hline & & $\mathrm{M}=\mathrm{Cr}$ & $\mathrm{M}^{\prime}=\mathrm{W}$ & $\mathrm{R}=\mathrm{Me}$ & $\mathrm{R}^{\prime}=\mathrm{Me}$ & 5 \\
\hline & & $\mathrm{M}=\mathrm{Cr}$ & $\mathrm{M}^{\prime}=\mathrm{Cr}$ & $\mathrm{R}=\mathrm{Me}$ & $\mathrm{R}^{\prime}=\left(\mathrm{CH}_{2}\right)_{4} \mathrm{OMe}$ & 6 \\
\hline & & $\mathrm{M}=\mathrm{W}$ & $\mathrm{M}^{\prime}=\mathrm{W}$ & $\mathrm{R}=\mathrm{Me}$ & $\mathrm{R}^{\prime}=\left(\mathrm{CH}_{2}\right)_{4} \mathrm{OMe}$ & 7 \\
\hline & & $\mathrm{M}=\mathrm{W}$ & $\mathrm{M}^{\prime}=\mathrm{W}$ & $\mathrm{R}=\left(\mathrm{CH}_{2}\right)_{4} \mathrm{OMe}$ & $\mathrm{R}^{\prime}=\left(\mathrm{CH}_{2}\right)_{4} \mathrm{OMe}$ & 8 \\
\hline \multirow[t]{4}{*}{$\mathrm{X}=\mathrm{NMe}, \mathrm{Y}=\mathrm{NMe}$} & $n=0$ & $\mathrm{M}=\mathrm{Cr}$ & & $\mathrm{R}=\mathrm{Et}$ & & 9 \\
\hline & & $\mathrm{M}=\mathrm{W}$ & & $\mathrm{R}=\mathrm{Et}$ & & 10 \\
\hline & $n=1$ & $\mathrm{M}=\mathrm{Cr}$ & $\mathrm{M}^{\prime}=\mathrm{Cr}$ & $\mathrm{R}=\mathrm{Et}$ & $\mathrm{R}^{\prime}=\mathrm{Et}$ & 11 \\
\hline & & $\mathrm{M}=\mathrm{W}$ & $\mathrm{M}^{\prime}=\mathrm{W}$ & $\mathrm{R}=\mathrm{Et}$ & $\mathrm{R}^{\prime}=\mathrm{Et}$ & 12 \\
\hline \multirow[t]{6}{*}{$\mathrm{X}=\mathrm{S}, \mathrm{Y}=\mathrm{O}$} & $n=0$ & $\mathrm{M}=\mathrm{Cr}$ & & $\mathrm{R}=\mathrm{Me}$ & & 13 \\
\hline & & $\mathrm{M}=\mathrm{W}$ & & $\mathrm{R}=\mathrm{Me}$ & & 14 \\
\hline & $n=1$ & $\mathrm{M}=\mathrm{Cr}$ & $\mathrm{M}^{\prime}=\mathrm{Cr}$ & $\mathrm{R}=\mathrm{Me}$ & $\mathrm{R}^{\prime}=\mathrm{Me}$ & 15 \\
\hline & & $\mathrm{M}=\mathrm{W}$ & $\mathrm{M}^{\prime}=\mathrm{W}$ & $\mathrm{R}=\mathrm{Me}$ & $\mathrm{R}^{\prime}=\mathrm{Me}$ & 16 \\
\hline & & $\mathrm{M}=\mathrm{Cr}$ & $\mathrm{M}^{\prime}=\mathrm{W}$ & $\mathrm{R}=\mathrm{Me}$ & $\mathrm{R}^{\prime}=\mathrm{Me}$ & 17 \\
\hline & & $\mathrm{M}=\mathrm{W}$ & $\mathrm{M}^{\prime}=\mathrm{Cr}$ & $\mathrm{R}=\mathrm{Me}$ & $\mathrm{R}^{\prime}=\mathrm{Me}$ & 18 \\
\hline \multirow[t]{2}{*}{$\mathrm{X}=\mathrm{S}, \mathrm{Y}=\mathrm{NMe}$} & $n=0$ & $\mathrm{M}=\mathrm{Cr}$ & & $\mathrm{R}=\mathrm{Et}$ & & 19 \\
\hline & & $\mathrm{M}=\mathrm{W}$ & & $\mathrm{R}=\mathrm{Et}$ & & 20 \\
\hline
\end{tabular}

inert atmosphere in the solid state, whereas the monocarbene complexes are stable.

Three procedures, taking into account the best conditions for the dimetallation of S1-S4 as well as the most effective way to achieve a reaction with the metal hexacarbonyl, were used for the synthesis of the carbene complexes.

Method 1. Dilithiated bithiophene was reacted with the metal hexacarbonyl at low temperature and alkylation of the intermediated products with methyl trifluoromethanesulfonate affording the mono- and biscarbene complexes (1-4) as well as complexes where alkylation proceeded via ring opening of tetrahydrofuran (6-8). Dötz and co-workers ${ }^{25}$ were the first to observe an opening of the THF ring during alkylation of Fischer carbene complexes with magic methyl. Raubenheimer and co-workers reported the formation of similar compounds during the alkylation of carbene complexes containing an azolyl organic substituent. ${ }^{26}$ A similar reaction leading to THF ring opening has been observed in our laboratories with $\pi$-coordinated thienyl chromium tricarbonyl substituents. ${ }^{27}$ The THF insertion is initiated by a nucleophilic attack of the metal acyllate on the $\alpha$-carbon of the THF leading to ring cleaving and the formation of the butoxy(methoxy) carbene complexes (Scheme 2).

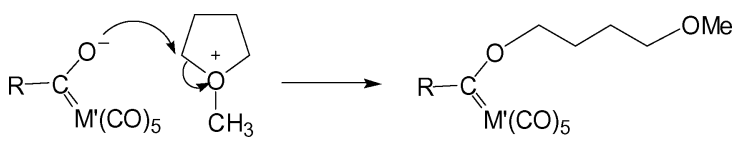

Scheme 2 Ring-opening of THF during alkylation of 6-8.

The alkylation of the tungsten derivatives was carried out in two ways. In the first attempt THF was used as solvent for the alkylation and large quantities of $7(28 \%)$ and $8(17 \%)$ were isolated. These complexes displayed a high retention on a silica gel column which complicated purification and led to significant losses, of $\mathbf{8}$ especially, where two equivalents of THF were incorporated. The synthesis was repeated by first removing all solvents in vacuo followed by washing the residue with aliquots of hexane. Hence the remaining THF was removed before carrying out the alkylation in dichloromethane. Surprisingly, the butoxy(methoxy) carbene complexes $\mathbf{7}$ and $\mathbf{8}$ were formed again, albeit in a lower yield (10\% and $7 \%$ respectively). This was also observed during the synthesis of the chromium derivatives with $10 \%$ of 6 isolated after alkylation in dichloromethane. The chromium analogue of 8 was not isolated and characterised since sufficient quantities could not be removed from the silica gel column. These results indicated that the incorporated THF might be associated with an intermediate acyl metallate or be trapped in the residue and is thus not eliminated during the removal of the solvent under reduced pressure.

Method 2. In the second procedure, used for $\mathrm{N}, \mathrm{N}^{\prime}$ dimethylbipyrrole complexes, a mixture of lithiated and dilithiated $\mathrm{N}, \mathrm{N}^{\prime}$-dimethylbipyrrole (S2) was obtained from $n$-BuLi/TMEDA in hexane at elevated temperatures. ${ }^{28}$ This mixture was added at low temperature to a THF solution containing the metal carbonyl. Alkylation with triethyloxonium tetrafluoroborate afforded monocarbene complexes $(\mathbf{9}, \mathbf{1 0})$ in yields of $20-30 \%$ and biscarbene complexes $(\mathbf{1 1}, \mathbf{1 2})$ in yields of $35-45 \%$. When applied to $\mathbf{S 4}$, no dinuclear biscarbene complexes formed and only monocarbene complexes were found, on the $\alpha$-position of the thiophene moiety.

Method 3. This route comprised a modified version of a method used by Aoki involving a stepwise lithiation procedure and anionic protection of the formed monoacyl metallate (Scheme 3). ${ }^{29}$ This method, which worked well, was previously used in our laboratories to prepare the mixed metal $(\mathrm{Cr}, \mathrm{W})$ biscarbene complex of

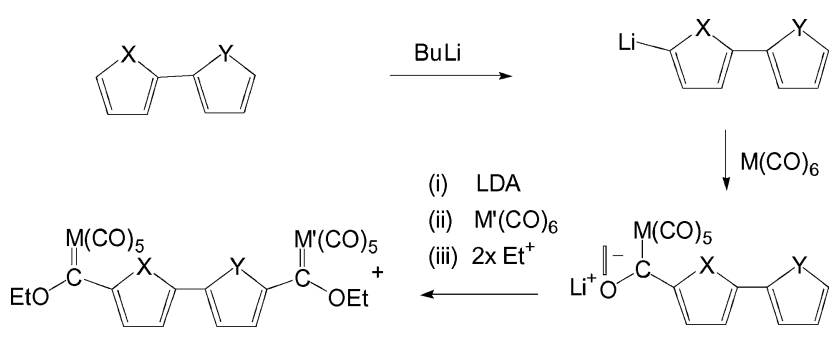

Scheme 3 Method of anionic protection during the synthesis of mixed metal biscarbene complexes. 
furan. ${ }^{30}$ In this particular study, the method was applied to prepare 5,17 and 18 and also to increase yields of homonuclear biscarbene complexes $\mathbf{3}, \mathbf{4}, \mathbf{6}, \mathbf{7}, \mathbf{8}, \mathbf{1 5}$ and $\mathbf{1 6}$. In the case of bithiophene, $\mathbf{S 1}$ was monolithiated and reacted with $\mathrm{Cr}(\mathrm{CO})_{6}$ or $\mathrm{W}(\mathrm{CO})_{6}$. The reaction mixture was cooled to $-70{ }^{\circ} \mathrm{C}$, the proton of the acyl metallate was removed from position 9 by freshly prepared LDA and the mixture reacted with a second metal carbonyl precursor. For 5, after alkylation with methyl trifluoromethanesulfonate, the isolated yield of the $\mathrm{Cr}, \mathrm{W}$-bithiophene biscarbene complex was low compared to that reported for the furan analogue $(12 \%$ versus $47 \%$ ). Similar quantities of the corresponding monocarbene complexes of bithienyl, butyl (from $n$-BuLi) and diisopropylamide (from LDA) substituents were also isolated from the reaction mixture.

S3 was mono-lithiated, treated with $\mathrm{M}(\mathrm{CO})_{6}$ to form the acyl metallate and subsequently a second proton was abstracted with LDA. The resulting dianion was reacted with a second equivalent of $\mathrm{M}(\mathrm{CO})_{6}$ followed by alkylation with methyl trifluoromethanesulfonate in dichloromethane. The monocarbene complexes 13 and 14 were the main products isolated together with the homometallic biscarbene complexes 15 and 16. By-products that formed but were not purified, include butyl carbene complexes as well as carbene complexes with incorporated THF in the alkoxy substituent.

Because of the higher temperatures required to deprotonate $\mathbf{S 2}$, this method was not used during the synthesis of 9-12.

Only monocarbene complexes could be isolated using method 1 for $\mathbf{S 4}(\mathbf{1 9}, \mathbf{2 0})$ as excess $n$-BuLi and harsher reaction conditions lead to pyrrole-thiophene bond cleavage resulting from the nucleophilic addition of butyl on the thiophene side of the interring bond.

In synthesizing mixed metal biscarbene complexes 17 and 18, the composition of the final biscarbene complex was determined by the order of metal hexacarbonyl precursor addition. Finally, the sensitivity and selectivity of a specific metal site towards carbon-carbon coupling reactions were tested for selected examples.

\section{Benzannulation reactions}

The selectivity of a specific metal site and/or the role of the heteroatom in the heteroarene ring was tested by reacting the appropriate biscarbene complex with 3-hexyne in the well known Dötz reaction for Fischer carbene complexes. ${ }^{31}$ Heteroaryl monocarbene complexes with furyl, thienyl and pyrrolyl substituents also undergo Dötz reactions. ${ }^{16 \mathrm{~d}, 32}$ Wulff and coworkers $^{33}$ optimised the reaction conditions for monocarbene complexes with phenyl substituents to afford naphthol products. The chromium complexes displayed the highest selectivity to afford products where the insertion of a carbonyl leads to benzannulation products. Optimal conditions are found with higher metal concentrations and with less polar or coordinating solvents and were applied in the reactions of complexes $\mathbf{3}, \mathbf{5}$ and 15 with 3-hexyne. Very few accounts of the reactions of biscarbene complexes with alkynes have been reported ${ }^{34}$ and as far as we are aware the only other example starting from mixed metal biscarbene complexes with heteroarene substituents was reported earlier from our laboratories. ${ }^{30}$ The present study deals only with the major products formed during the reactions and no attempt has been made to isolate intermediates or minor organic products. The reactions of the biscarbene metal complexes with 3-hexyne were carried out in toluene at $80{ }^{\circ} \mathrm{C}$ with a metal concentration of $0.1 \mathrm{~mol} \mathrm{dm}^{-3}$ and 4 molar equivalents of alkyne. Higher concentrations of the metal complexes were not possible because of their poor solubility in toluene. Reactions were allowed to proceed for $24 \mathrm{~h}$ after which the major coloured product was isolated with column chromatography and characterised by NMR and infrared spectroscopy, and mass spectrometry. The composition of the products is shown in Scheme 4.

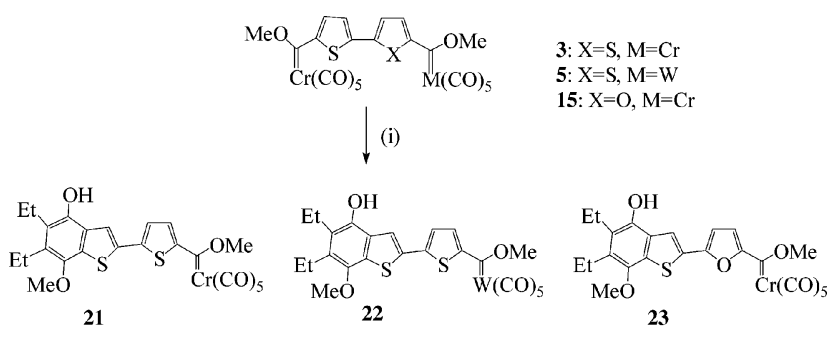

(i) 3-hexyne; toluene; $80^{\circ} \mathrm{C}$ for $24 \mathrm{~h}$

Scheme 4 Regioselective benzannulation reactions of biscarbene complexes.

The modified bithiophene monocarbene complex 21 was the major product from the reaction of $\mathbf{3}$ with 3 -hexyne. For the mixed $\mathrm{Cr}, \mathrm{W}$-binuclear biscarbene complex $\mathbf{5}$ the formation of $\mathbf{2 2}$ was not unexpected since it is generally known that for mononuclear carbene complexes of chromium, the carbonyl ligands are more labile compared to analogous tungsten carbonyl complexes. This will favour the carbonyl insertion step in the formation of the benzothiophene unit during the reaction and make the chromium carbene site the preferred centre for the benzannulation reaction. This result demonstrated that regioselective discrimination between the two different metal carbene sites $(\mathrm{Cr}, \mathrm{W})$ is possible for this particular reaction, as well as simultaneous protection of a second metal carbene centre. In addition to this, no other simple route is known to exist to synthesize 22, the tungsten monocarbene analogue to the modified chromium carbene complex 21. The formation of $\mathbf{2 3}$ from $\mathbf{1 5}$ illustrates the role of the heteroatom in the arene rings (thiophene $v s$. furan) to direct the reaction and determine the composition of the product.

\section{Carbene coupling reactions}

Early work on the reactivity of Fischer carbene complexes focused on the ability of these to act as stable carbene sources. Amongst others, it was found that the carbene ligand undergoes thermal dimerization, ${ }^{35}$ yields esters through oxidative decomposition ${ }^{36}$ and form cyclopropanes through carbene transfer to activated alkenes. ${ }^{37}$ In a second example the objective was to study carbenecarbene coupling reactions in the presence of a palladium catalyst. Sierra and co-workers ${ }^{38}$ have demonstrated that palladium catalysts can effectively facilitate the carbene-carbene coupling of monocarbene complexes. The product (Fig. 2) is representative of the coupling of two dithienothiophene carbene ligands and represents a situation whereby a growing $\pi$-conjugated chain 


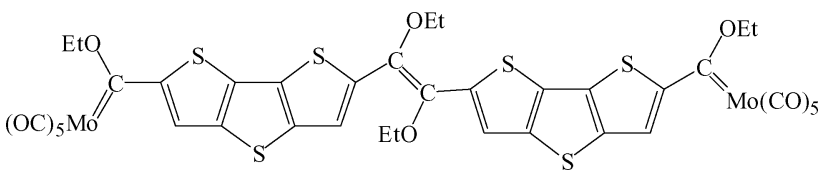

Fig. 2 Carbene-carbene coupled biscarbene complex of molybdenum.

of dithienothiophene units is found between two molybdenum carbene ligands. ${ }^{39}$

The monocarbene complexes 13 and 19, and biscarbene complex 15 were dissolved in THF and refluxed with a catalytic amount of $\mathrm{Pd}\left(\mathrm{PPh}_{3}\right)_{4}$ until all of the carbene precursors were reacted to form the products 24, 25 and 26, respectively (Scheme 5). Complex 13 and 19 reacted completely to exclusively form the E-isomeric carbene-carbene coupled olefins $\mathbf{2 4}$ and $\mathbf{2 5}$. A minor by-product (3\% yield) was 2-thienylfuran ethyl acetate for the reaction of 13. The reaction of the biscarbene complex $\mathbf{1 5}$ under similar conditions leads to some decomposition, no olefin formation, and mainly the 2, 5'-diester complex 26. We ascribe the formation of 26 to trace amounts of atmospheric oxygen entering the system during the refluxing of reagents in THF. Monocarbene ester complexes generally formed during the synthesis of biscarbene complexes as a secondary reaction product. ${ }^{15 a, 17,18}$
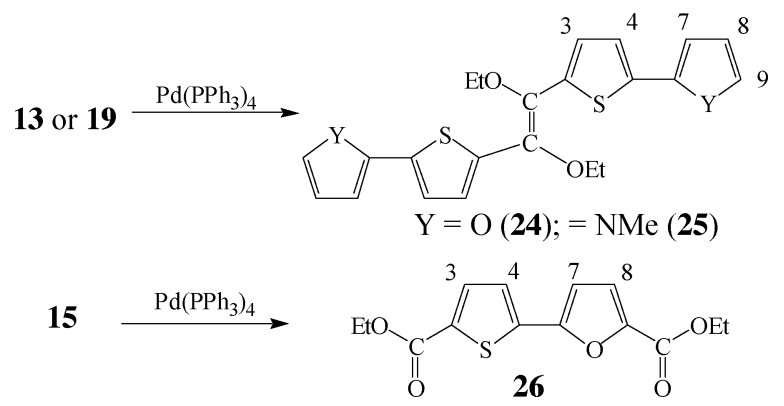

Scheme 5 Carbene coupling reactions with a palladium catalyst.

\section{Characterization of substrates and complexes}

Complexes 1-20 were characterized using infrared and ${ }^{1} \mathrm{H}$ NMR spectroscopy as well as mass spectrometry. Suitable crystals of 12, 14 and 20 were obtained from dichloromethane-hexane solutions for X-ray diffraction studies.

The infrared frequencies and patterns observed in the carbonyl region confirm the presence of the $\mathrm{M}(\mathrm{CO})_{5}$-fragment for all the complexes.

The coordination of the metal fragment via an electrophilic carbene carbon atom has a significant effect on the electronic environment of the remaining ring protons of the heteroarene rings and is reflected in the downfield chemical shift values recorded in the ${ }^{1} \mathrm{H}$ NMR spectra of the heterocycles as spacers in the complexes (1-20) compared to the heterocycles (S1-S4). The H3 resonances of thiophene rings are most affected by coordination of the carbene ligand to the transition metal. Interestingly, the chemical shifts of the thiophene directly bonded to the carbene carbon atom show striking similarities for the complexes of S1, S3 and S4. Despite different heteroaromatic substituents on the thiophene ring in the monocarbene complexes $(\mathbf{1}, \mathbf{2}, \mathbf{1 3}, \mathbf{1 4})$, virtually identical chemical shifts were observed for $\mathrm{H} 3$ for the chromium $(8.18,8.19 \mathrm{ppm})$ and the tungsten complexes (8.09$8.11 \mathrm{ppm})$. In the monocarbene complexes the ${ }^{1} \mathrm{H}$ NMR data indicates that the carbene moiety withdraws electron density mainly from the ring to which it is bonded.

In the symmetric, homonuclear biscarbene complexes of bithiophene $(\mathbf{3}, \mathbf{4}) \mathrm{H} 3$ and $\mathrm{H} 8$, and $\mathrm{H} 4$ and $\mathrm{H} 7$ are equal, but not so for the bipyrrole complex 12, which has a distorted structure in the solid state due to steric crowding caused by the positioning of the two N-methyl groups in the complex (vide infra). Comparison of the chemical shifts of the protons in the furan $(\mathbf{S 3})$ or $\mathrm{N}$ methylpyrrole (S4) moiety to those observed for the monocarbene complexes of furan in thienylfuran or $\mathrm{N}$-methylpyrrole in $\mathrm{N}$ methyl(thienyl)pyrrole $(\mathbf{1 3}, \mathbf{1 4}, \mathbf{1 9}, \mathbf{2 0})$, indicate that the thiophene ring withdraws electron density from the furan and pyrrole rings as well. Thus the chemical shifts of $\mathrm{H} 7$ and $\mathrm{H} 8$ are shifted downfield for both the tungsten and chromium derivates with a more pronounced effect on $\mathrm{H} 7$. In the heteronuclear biscarbene complex 5 the chemical shifts of $\mathrm{H} 3$ and $\mathrm{H} 8$ reflect the nature of the metal bonded to the adjacent carbene carbon; $\mathrm{H} 3$ resonates at $8.16 \mathrm{ppm}$ in 5 whilst a value of $8.17 \mathrm{ppm}$ is observed for the analogous homonuclear chromium complex 1. On the tungsten end of the ligand in $\mathbf{5}$ the chemical shift observed for $\mathrm{H} 8$ is $8.08 \mathrm{ppm}$ which is almost the same for the analogous homonuclear tungsten complex $\mathbf{2}$ displaying a value of $8.09 \mathrm{ppm}$.

Indicative of the electrophilic nature of the carbene carbon is the donation of electron density from the oxygen lone pairs affecting the methyl/methylene protons of the alkoxy substituent which is also a function of the metal bonded to the carbene carbon. In the monocarbene complexes for chromium the values for the methyl protons are $4.79 \mathrm{ppm}(\mathbf{1}, \mathbf{1 3})$ whereas those for tungsten are upfield, $4.63 \mathrm{ppm}(2, \mathbf{1 4})$. In the homonuclear biscarbene complexes 3 and $\mathbf{1 5}$ for chromium and $\mathbf{4}$ and $\mathbf{1 6}$ for tungsten these resonances are slightly downfield. A similar situation is found for the methylene protons of the ethoxy substituents in $\mathbf{9}$ and $\mathbf{1 1}$ for chromium and $\mathbf{1 0}$ and $\mathbf{1 2}$ for tungsten. In the mixed metal biscarbene complexes (5, $\mathbf{1 7}, \mathbf{1 8})$ the metal identity is again reflected in the methyl resonances of the methoxy substituent.

The ${ }^{13} \mathrm{C}$ NMR data of the mono and biscarbene complexes correspond well for both the chromium and tungsten complexes and are determined only by the nature of the metal involved. The carbonyl carbon atoms resonate at the same values e.g. $223 / 217$ and 202/198 ppm for the trans/cis resonances of the chromium/tungsten carbonyl ligands, respectively. The carbene carbon chemical shifts are also found in a narrow range of values determined by the metal rather than the other substituents on the carbene ligand. The carbene carbon resonates between 309 , $310(\mathbf{1 7}, \mathbf{1 9})$ and $317 \mathrm{ppm}(\mathbf{5}, \mathbf{1 5})$ for the chromium and 284, $285(\mathbf{1 7}, \mathbf{2 0})$ and $291 \mathrm{ppm}(\mathbf{4}, \mathbf{5}, \mathbf{7})$ for the tungsten carbene complexes. The heteronuclear biscarbene complexes $(\mathbf{5}, \mathbf{1 7}, \mathbf{1 8})$ exhibit the expected varying carbene carbon ${ }^{13} \mathrm{C}$ NMR signals corresponding to the different metal carbonyl substituents on the carbene carbons and are reflected in the two sets of metal carbonyl resonances. The heteroarene ring chemical shifts are little affected by the electrophilic carbene carbon and the nature of the metal. The signals for $\mathrm{C} 2$ of the heteroarene substituents are slightly downfield for the tungsten carbene complexes compared to the corresponding signals for the chromium analogues 
( $\Delta=2 \mathrm{ppm}$ ). Ring assignments for $\mathbf{S 3}$-complexes were supported by $2 \mathrm{D}$ HETCOR experiments.

\section{Description of crystal structures}

Single crystal X-ray diffraction studies confirmed the molecular structures of 12, 14 and 20. Complex 14 crystallizes in two different conformational isomers as shown in Fig. 3. Selected bond lengths and angles are given in Table 2, crystal structure data are given in Table 3, and Fig. 3-5 show anisotropic displacement ellipsoid representations of the structures. The six ligands, five carbonyl groups and one carbene ligand, are arranged octahedrally around each metal centre. The carbene carbon and the methoxy
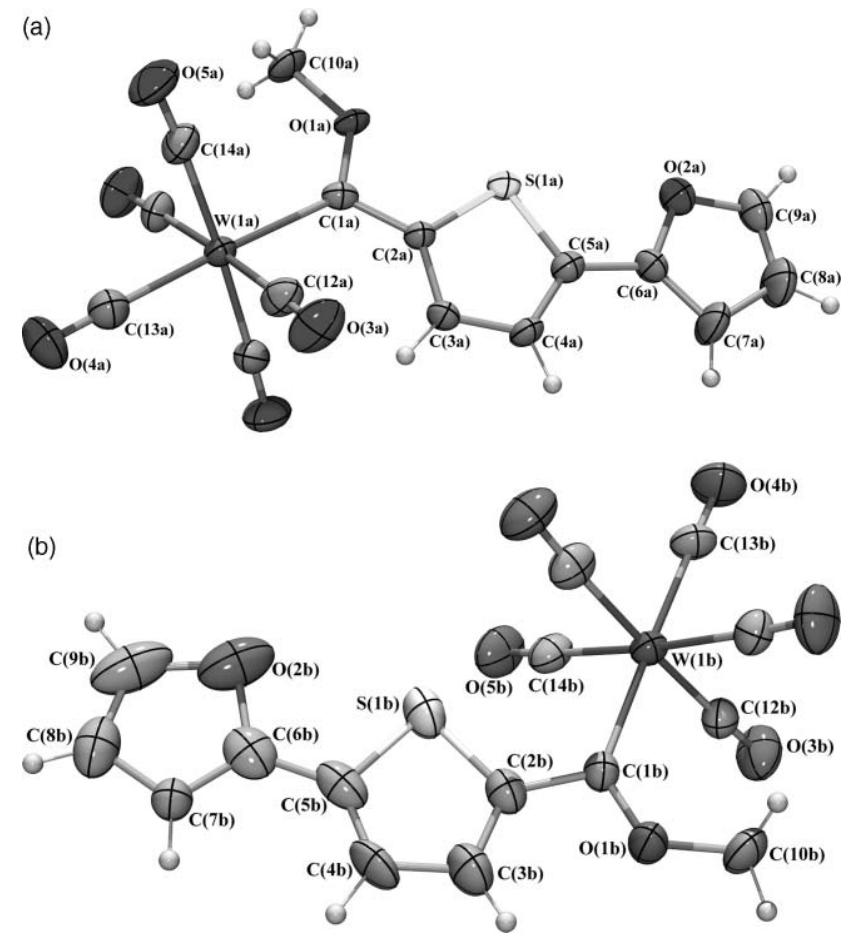

Fig. 3 Molecular structures of the conformational isomers 14A and 14B showing the atom numbering scheme, ADP ellipsoids are shown at the $50 \%$ probability level.

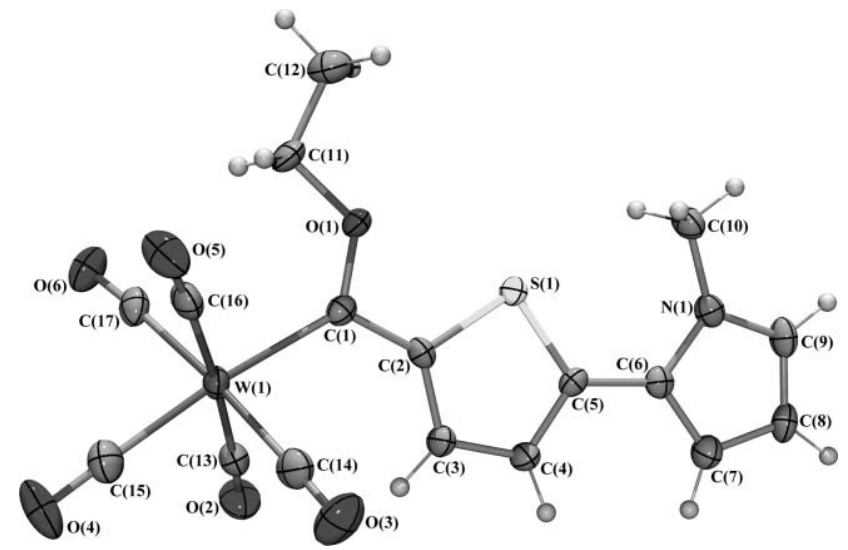

Fig. 4 Molecular structure of complex 20 showing the atom numbering scheme, ADP ellipsoids are shown at the $50 \%$ probability level.

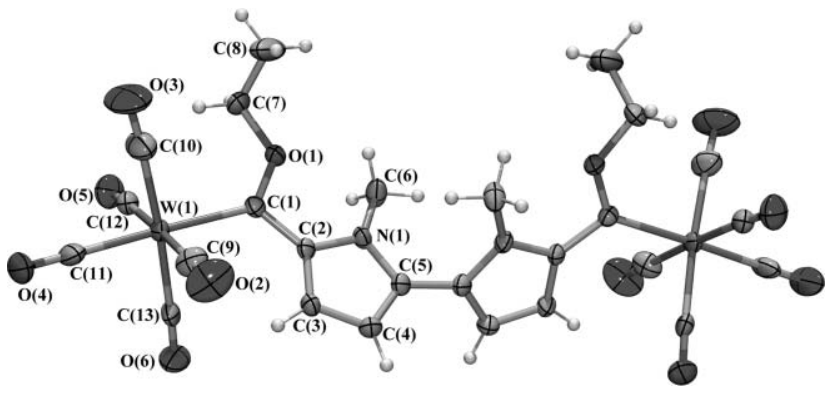

Fig. 5 Molecular structure of complex 12 showing the atom numbering scheme, ADP ellipsoids are shown at the $50 \%$ probability level.

substituent are coplanar with the thienylfuran rings in $\mathbf{1 4}$ allowing for electron conjugation in the spacer.

This is also true for $\mathbf{2 0}$ but is not the case for $\mathbf{1 2}$ where the close proximity and bulkiness of two $\mathrm{N}$-methyl groups force the rings to twist out of co-planarity, resulting in an NCCN dihedral angle of $61.5(2)^{\circ}$ and making electron delocalization between the two rings impossible. The two conformational isomers of $\mathbf{1 4}$ differ in the orientation of the tungsten carbonyl moiety with respect to the sulfur atom of the attached thienyl ring. In $\mathbf{1 4 A}$ the $\mathrm{W}(\mathrm{CO})_{5}$ fragment is positioned away from the sulfur atom of the ring, with the methoxy substituent of the carbene ligand found on the same side as the sulfur atom. In $14 \mathrm{~B}$ the $\mathrm{W}(\mathrm{CO})_{5}$ fragment is on the same side as the sulfur atom as a result of an $180^{\circ}$ rotation around the carbene carbon and ipso-thiophene carbon bond on going from $14 \mathrm{~A}$ to $14 \mathrm{~B}$. Both 12 and 20 have similar structures to $14 \mathrm{~A}$. This arrangement represents the preferred conformation in many analogous complexes studied in our laboratories and we ascribe this to two factors. They are: (i) the stabilization of the lithiated intermediate by heteroatoms during the reaction of the metallated substrate and the metal carbonyl precursor and (ii) the inhibition of rotation after alkylation due to electron delocalization around the carbene carbon and heteroarene carbon bond. The latter isomer may either originate from electronic or steric properties after alkylation. Such a hypothetic dilithiated intermediate is shown in Fig. 6 for the bistungsten acyl metallate with a N,N'dimethylbipyrrole spacer. The induced conformational properties of the carbene substituents are retained because of charge delocalization from the heteroarene ring to the electrophilic carbene carbon atom or the restriction of free rotation of the carbene substituents. In fact, this orientation is also retained for the $\mathrm{N}, \mathrm{N}^{\prime}$ dimethylbipyrrole spacers at both carbene sites in the solid state in spite of the bulky methyl substituents that hinder rotation around the carbon-carbon bond between the two pyrrole rings. Notably only one set of chemical shifts is observed in both the $\mathrm{H}$ and C NMR spectra of $\mathbf{1 4}$. This could suggest that isomerization at

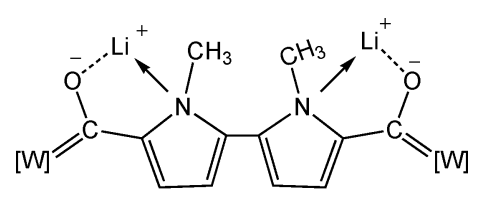

$$
[\mathrm{W}]=\mathrm{W}(\mathrm{CO})_{5}
$$

Fig. 6 Proposed dilithiated intermediate stabilized by two metallacyclic five-membered rings. 
Table 2 Selected bond lengths $(\AA)$, angles $\left({ }^{\circ}\right)$, and dihedral angles $\left({ }^{\circ}\right)$ for $\mathbf{1 2}, \mathbf{1 4}$ and $\mathbf{2 0}$ with estimated standard deviations in parentheses ${ }^{a}$

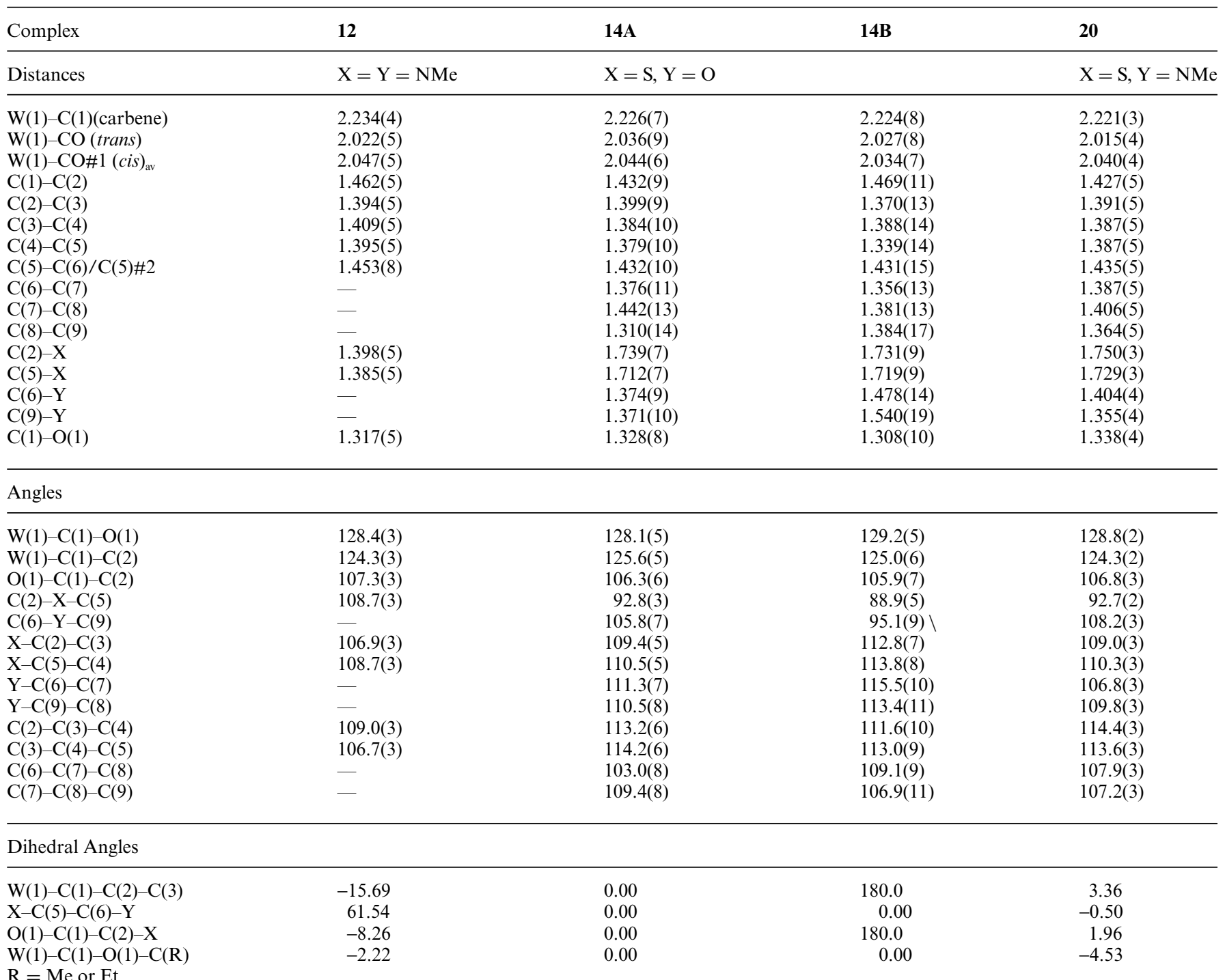

$\mathrm{R}=\mathrm{Me}$ or $\mathrm{Et}$

${ }^{a}$ Symmetry transformations used to generate equivalent atoms: $\# 1 x,-y+1 / 2, z$ for $\mathbf{1 4}$ and $\# 2-x+1 / 2,-y+3 / 2, z$ for $\mathbf{1 2}$.

room temperature in solution is rapid or that the structures differ insignificantly in their chemical shifts.

A view down the $c$-axis of $\mathbf{1 4}$ (Figure 7) reveals a layered structure of alternating $\mathbf{A}$ and B-type conformers and layers defined by the stacking of thienylfuran rings (inter-plane distances are $3.742 \AA$ ). For both the $\mathbf{A}$ and $\mathbf{B}$ conformers the plane of the carbene ligand lies in a mirror plane and hence it exactly bisects the carbonyl ligands in the equatorial plane. Even though planes through successive heteroarene rings in $\mathbf{2 0}$ are closer (3.526 compared to those in $\mathbf{1 4}$, the same layered structure is not found. In all the structures, the alkyl groups are orientated towards the $\mathrm{W}(\mathrm{CO})_{5}$-fragments while the oxygen lone pairs point towards the heteroarene rings. Sierra and co-workers ${ }^{40}$ ascribe this to an electronic and steric advantage in alkoxy carbene complexes for the lone pair electrons to avoid the "carbonyl wall" of the $\mathrm{W}(\mathrm{CO})_{5}$ fragment.

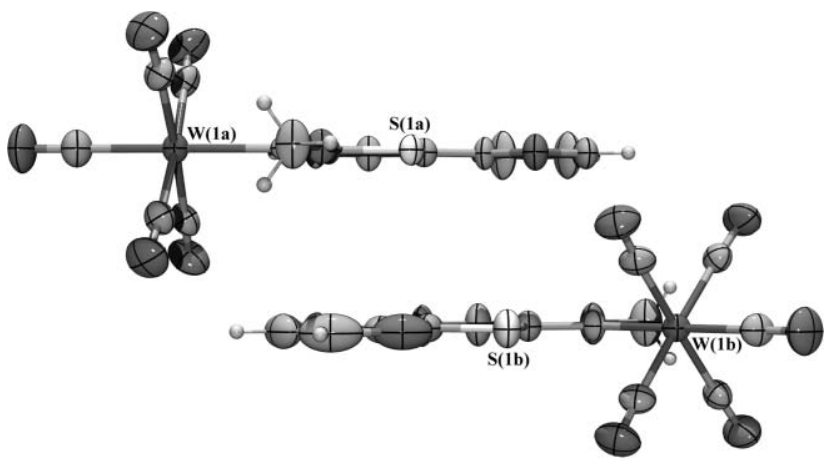

Fig. 7 View down the $c$-axis to show the layered packing of $\mathbf{1 4}$

The bond lengths and angles do not differ significantly between the structures. The corresponding $\mathrm{W}-\mathrm{C}$ (carbene) distances and 
Table 3 Crystal structure data for 12, 14 and 20

\begin{tabular}{|c|c|c|c|}
\hline & 12 & 14 & 20 \\
\hline Formula & $\mathrm{C}_{26} \mathrm{H}_{20} \mathrm{~N}_{2} \mathrm{O}_{12} \mathrm{~W}_{2}$ & $\mathrm{C}_{15} \mathrm{H}_{8} \mathrm{O}_{7} \mathrm{SW}$ & $\mathrm{C}_{17} \mathrm{H}_{13} \mathrm{NO}_{6} \mathrm{SW}$ \\
\hline$M_{\mathrm{r}}$ & 920.14 & 516.12 & 543.19 \\
\hline Cryst. size $/ \mathrm{mm}^{3}$ & $0.05 \times 0.05 \times 0.05$ & $0.08 \times 0.07 \times 0.06$ & $0.06 \times 0.06 \times 0.04$ \\
\hline Crystal system & Orthorhombic & Orthorhombic & Monoclinic \\
\hline Space group & Pccn & Pnma & $P 2_{1} / c$ \\
\hline$a / \AA ̊$ & $17.7003(6)$ & $30.1832(9)$ & $7.4036(2)$ \\
\hline$\alpha /^{\circ}$ & 90 & 90 & 90 \\
\hline$\beta /^{\circ}$ & 90 & 90 & $96.655(2)$ \\
\hline$\gamma /^{\circ}$ & 90 & 90 & 90 \\
\hline$V / \AA^{3}$ & $3000.3(2)$ & $3313.6(2)$ & $1825.84(8)$ \\
\hline$Z$ & 4 & 8 & 4 \\
\hline$D_{\text {calcd }} / \mathrm{g} \mathrm{cm}^{-3}$ & 2.037 & 2.069 & 1.976 \\
\hline Completeness to $\theta=27.50^{\circ}(\%)$ & 99.7 & 97.4 & 100 \\
\hline Max. and min. transmission & 0.625 and 0.697 & 0.584 and 0.536 & 0.629 and 0.745 \\
\hline Refl. Measured & 18869 & 10908 & 18618 \\
\hline Refl. Unique & 3431 & 3994 & 4186 \\
\hline$R_{\text {int }}$ & 0.0563 & 0.0437 & 0.0449 \\
\hline Param. Refined & 190 & 265 & 235 \\
\hline$R(F) / w R\left(F^{2}\right)[I>2 \sigma(I)]$ & $0.0313 / 0.0663$ & $0.0342 / 0.0831$ & $0.0268 / 0.0550$ \\
\hline$R(F) / w R\left(F^{2}\right)$ [all data] & $0.0445 / 0.0709$ & $0.0448 / 0.0879$ & $0.0385 / 0.0590$ \\
\hline $\operatorname{GoF}\left(F^{2}\right)$ & 1.054 & 1.017 & 0.959 \\
\hline$\Delta \rho_{\text {fin }}(\max / \min ) / \mathrm{e} \AA^{-3}$ & $0.643 /-1.392$ & $1.865 /-2.403$ & $0.549 /-1.001$ \\
\hline
\end{tabular}

inter-ring $\mathrm{C}-\mathrm{C}$ distances are similar, but comparisons are complicated because of the large margin of error in the measurements, especially in $\mathbf{1 4 .}$

\section{Conclusion}

Mononuclear carbene and binuclear biscarbene complexes with electron rich heteroaromatic substituents were synthesized. Structural studies revealed favorable planar arrangements and orientations for the carbene substituents to maximize electronic interaction and minimize steric strain in these molecules. A synthetic method was devised to synthesize biscarbene complexes containing different metal fragments at the ends of the conjugated bridging heteroarene linkers. In doing so, two reactive and potentially very different carbene functionalities exist in the same molecule. In addition to the enhanced reactivities at the carbene centers, ${ }^{15,17,18}$ the potential of regioselective and stereoselective modifications at the carbene centers become very attractive features to exploit. In preliminary experiments the well known benzannulation reaction with 3-hexyne revealed competitive reaction sites which were determined by the nature of the metal carbonyl fragment and the type of heteroatom in the biheteroaryl substituent. Metal-metal communication via heteroarene spacers and carbene ligands in metal cluster compounds is not only of interest in studying the template chemistry of such compounds but also creates exciting new opportunities for application of the carbene functionality in new materials and are being investigated further in our laboratories. ${ }^{41}$

\section{Experimental}

\section{General procedures}

All manipulations involving organometallic compounds made use of Schlenk techniques, and operations were carried out under an inert atmosphere. Hexane, THF and dichloromethane were dried and deoxygenated by distillation prior to use. Commercial thiophene was purified, ${ }^{42}$ triethyloxonium tetrafluoroborate ${ }^{43}$ and the phosphine catalysts of palladium utilized in the preparation of the heteroaryls, $\mathrm{Pd}\left(\mathrm{PPh}_{3}\right)_{4}$ and $\mathrm{Pd}(\mathrm{dppf})_{2} \mathrm{Cl}_{2}$, were prepared according to reported procedures. ${ }^{44}$ Melting points of the carbene complexes were not recorded because of their decomposition on heating. TMEDA was distilled before use. The reagents $\mathrm{W}(\mathrm{CO})_{6}$, methyl trifluoromethanesulfonate, butyl lithium $\left(1.6 \mathrm{mmol} \mathrm{mL} \mathrm{m}^{-1}\right.$ solution in hexane) and all other commercial agents were used as purchased. Traces of water were removed from $\mathrm{ZnCl}_{2}$ azeotropically with toluene or heated to $80^{\circ} \mathrm{C}$ under reduced pressure for $8 \mathrm{~h}$. Column chromatography, using silica gel 60 (0.0063-0.200 mm) as the stationary phase, was employed for all separations and purifications. Circulating cold water through the column jackets cooled columns. NMR spectra were recorded on a Bruker ARX300 spectrometer and mass spectra on a Finnigan Mat 8200 instrument at $c a .70 \mathrm{eV}$ using the electron impact method. The NMR spectra were recorded in $\mathrm{CDCl}_{3}$ and the signal of the deuterated solvent was used as reference. ${ }^{1} \mathrm{H}$ and ${ }^{13} \mathrm{C} \mathrm{NMR}$ spectra were measured at 300.135 and $75.469 \mathrm{MHz}$, respectively. IR spectra were recorded on a Perkin-Elmer Spectrum RXI FT-IR spectrophotometer using hexane as solvent and only the vibration 
bands in the carbonyl-stretching region $\left(c a .1500-2200 \mathrm{~cm}^{-1}\right)$ are reported.

Bithiophene. (HTh-ThH, S1) ${ }^{19}$ was purchased from SigmaAldrich and the purity checked by NMR spectroscopy: ${ }^{1} \mathrm{H}$ NMR $\left(\mathrm{CDCl}_{3}, \mathrm{ppm}\right): \delta 7.21(\mathrm{dd}, \mathrm{H} 2,4.9,1.3 \mathrm{~Hz}), 7.02(\mathrm{dd}, \mathrm{H} 3,4.9$, $3.6 \mathrm{~Hz}), 7.18$ (dd, H4, 3.6, 1.3 Hz). $-{ }^{13} \mathrm{C} \mathrm{NMR}\left(\mathrm{CDCl}_{3}, \mathrm{ppm}\right) . \delta$ : 137 (C2), 124 (C3), 128 (C4), 124 (C5).

N,N'-dimethyldipyrrole. (HPyr-PyrH, S2). ${ }^{22} \quad{ }^{1} \mathrm{H} \quad \mathrm{NMR}$ $\left.\left(\mathrm{CDCl}_{3}, \mathrm{ppm}\right)\right): \delta 6.70(\mathrm{dd}, \mathrm{H} 2,2.70,1.81 \mathrm{~Hz}), 6.18(\mathrm{dd}, \mathrm{H} 3,2.7$, $3.49 \mathrm{~Hz}), 6.14(\mathrm{dd}, \mathrm{H} 4,3.49,1.81 \mathrm{~Hz})$.

Thienylfuran. (HTh-FuH, S3) ${ }^{20}{ }^{1} \mathrm{H}$ NMR $\left(\mathrm{CDCl}_{3}, \mathrm{ppm}\right): \delta$ 7.26 (dd, H2, 3.62, 1.3 Hz), 7.22 (dd, H3, 5.2, 1.3 Hz), 7.03 (dd, H4, 5.2, 3.6 Hz), 6.50 (dd, H7, 3.4, 0.8 Hz), 6.44 (dd, H8, 3.4, $1.8 \mathrm{~Hz}), 7.40$ (dd, H9, 5.2, $1.3 \mathrm{~Hz}) \cdot-{ }^{13} \mathrm{C} \mathrm{NMR}\left(\mathrm{CDCl}_{3}, \mathrm{ppm}\right): \delta$ 124 (C2), 128 (C3), 123 (C4), 134 (C5), 150 (C6), 112 (C7), 105 (C8), 142 (C9).

N-methylthienylpyrrole. (HTh-PyrH, S4) ${ }^{21}{ }^{1} \mathrm{H} \mathrm{NMR}\left(\mathrm{CDCl}_{3}\right.$, ppm): $\delta 7.25$ (dd, H2, 5.17, $1.29 \mathrm{~Hz}), 7.06(\mathrm{dd}, \mathrm{H} 3,5.17,3.62 \mathrm{~Hz}$ ), $7.01(\mathrm{dd}, \mathrm{H} 4,3.62,1.29 \mathrm{~Hz}), 6.32(\mathrm{dd}, \mathrm{H} 7,3.62,1.81 \mathrm{~Hz}), 6.16$ (dd, H8, 3.62, $2.59 \mathrm{~Hz}), 6.69$ (dd, H9, 2.59, 1.81 Hz). $\cdot{ }^{13} \mathrm{C}$ NMR $\left(\mathrm{CDCl}_{3}, \mathrm{ppm}\right): \delta 125$ (C2), 127 (C3), 124 (C4), 135 (C5), 128 (C6), 110 (C7), 108 (C8), 124 (C9).

Synthesis of metal carbene complexes from bithiophene(HTh-ThH)

\author{
Synthesis of $\left[\mathrm{W}(\mathrm{CO})_{5}\{\mathrm{C}(\mathrm{OMe}) \mathrm{Th}-\mathrm{ThH}\}\right]$, (2) \\ [(CO) $\left.)_{5} \mathrm{~W}\{\mathrm{C}(\mathrm{OMe}) \mathrm{Th}-\mathrm{ThC}(\mathrm{OMe})\} \mathrm{W}(\mathrm{CO})_{5}\right](4)$, \\ [ $\left.(\mathrm{CO})_{5} \mathrm{~W}\left\{\mathrm{C}(\mathrm{OMe}) \mathrm{Th}-\mathrm{ThC}\left(\mathrm{O}\left(\mathrm{CH}_{2}\right)_{4} \mathrm{OMe}\right)\right\} \mathrm{W}(\mathrm{CO})_{5}\right]$ (7) \\ $\left[(\mathrm{CO})_{5} \mathrm{~W}\left\{\mathrm{C}\left(\mathrm{O}\left(\mathrm{CH}_{2}\right)_{4} \mathrm{OMe}\right) \mathrm{Th}-\mathrm{ThC}\left(\mathrm{O}\left(\mathrm{CH}_{2}\right)_{4} \mathrm{OMe}\right)\right\} \mathrm{W}(\mathrm{CO})_{5}\right](8)$
}

To a THF solution $(30 \mathrm{~mL})$ containing bithiophene $(0.83 \mathrm{~g}$, $5.0 \mathrm{mmol})$ was added, after cooling to $-20{ }^{\circ} \mathrm{C}, n$-BuLi $(6.88 \mathrm{~mL}$, $11 \mathrm{mmol}$ ). The reaction mixture was stirred for 30 minutes and the temperature of the cold bath was lowered to $-40{ }^{\circ} \mathrm{C}$. Solid portions of $\mathrm{W}(\mathrm{CO})_{6}(3.51 \mathrm{~g}, 10 \mathrm{mmol})$ was slowly added and the mixture stirred for 30 minutes. The cold bath was removed and the brown reaction mixture stirred at room temperature for $1 \mathrm{~h}$. The reaction mixture was cooled to $-20{ }^{\circ} \mathrm{C}$ and methyl trifluoromethanesulfonate $(3.40 \mathrm{~mL}, 30 \mathrm{mmol})$ added. Alternatively, the solvent (THF) can be removed under reduced pressure, the residue washed with portions of hexane, dissolved in dichloromethane $(30 \mathrm{~mL})$ and cooled to $-20{ }^{\circ} \mathrm{C}$. The mixture was alkylated with methyl trifluoromethanesulfonate $(3.40 \mathrm{~mL}$, $30 \mathrm{mmol})$. In the first procedure the yields of $7(28 \%)$ and 8 $(17 \%)$ are much higher than in the second procedure $7(10 \%)$ and $8(17 \%)$. The solvent was removed after the alkylation was completed. The residue was absorbed on silica gel and placed on a silica gel column. Products were collected after eluting with a hexane: dichloromethane mixture, increasing polarity from a $4: 1$ to pure dichloromethane. The zones collected afforded 2, 4, 7 and $\mathbf{8}$.

\section{Characterization of products}

2: Yield $0.45 \mathrm{~g}$ (first method, $0.85 \mathrm{mmol}, 17 \%$ ) or $0.67 \mathrm{~g}$ (method 2, $1.25 \mathrm{mmol}, 25 \%$ ). Anal. calcd for $\mathrm{C}_{15} \mathrm{H}_{8} \mathrm{O}_{6} \mathrm{~S}_{2} \mathrm{~W}$ (532.2): C 33.86, H 1.51; Found: C 34.03, H 1.68 - MS (EI): $m / z$ (based on ${ }^{184} \mathrm{~W}$ ) $532[\mathrm{M}]^{+}$, stepwise fragmentation by loss of carbonyl ligands, 392
([M] $\left.]^{+}-5 \mathrm{CO}\right) .-{ }^{1} \mathrm{H}$ NMR $\left(\mathrm{CDCl}_{3}, \mathrm{ppm}\right): \delta 8.09$ (d, H3, $\left.4.4 \mathrm{~Hz}\right)$, 7.29 (d, H4, 4.4 Hz), 7.39 (dd, H7, 5.2, 1.2 Hz), 7.07 (dd, H8, 5.2, $3.6 \mathrm{~Hz}), 7.41$ (dd, H9, 3.6, $1.2 \mathrm{~Hz}), 4.63\left(\mathrm{~s}, \mathrm{COCH}_{3}\right) .-{ }^{13} \mathrm{C} \mathrm{NMR}$ $\left(\mathrm{CDCl}_{3}, \mathrm{ppm}\right): \delta 289(\mathrm{C} 1), 202\left(\mathrm{~W}(\mathrm{CO})_{5}\right.$, trans $), 198\left(\mathrm{~W}(\mathrm{CO})_{5}\right.$, cis), 155 (C2), 144 (C3), 125 (C4), 148 (C5), 136 (C6), 128 (C7), $129(\mathrm{C} 8), 126(\mathrm{C} 9), 68\left(\mathrm{COCH}_{3}\right)$ - IR (hexane, $\left.\mathrm{cm}^{-1}\right): v_{\mathrm{CO}}=2065$ (m), 1980 (vw), 1953 (s), 1944 (vs).

4. Yield $1.17 \mathrm{~g}$ (method $1,1.30 \mathrm{mmol}, 26 \%$ ) or $1.53 \mathrm{~g}$ (method 2, $1.70 \mathrm{mmol}, 34 \%$ ). Anal. calcd for $\mathrm{C}_{22} \mathrm{H}_{10} \mathrm{O}_{12} \mathrm{~S}_{2} \mathrm{~W}_{2}$ (898.2): $\mathrm{C}$ 29.42, H 1.12; Found: C 29.58, H 1.18 - MS (EI): $m / z$ (based on $\left.{ }^{184} \mathrm{~W}\right)[\mathrm{M}]^{+}$not observed.- ${ }^{1} \mathrm{H}$ NMR $\left(\mathrm{CDCl}_{3}, \mathrm{ppm}\right): \delta 8.08(\mathrm{~d}$, $\mathrm{H} 3 / \mathrm{H} 8,4.4 \mathrm{~Hz}), 7.46$ (d, H4/H7, $4.4 \mathrm{~Hz}), 4.65\left(\mathrm{~s}, \mathrm{OCH}_{3}\right) \cdot{ }^{-13} \mathrm{C}$ $\mathrm{NMR}\left(\mathrm{CDCl}_{3}, \mathrm{ppm}\right): \delta 291\left(\mathrm{Cl}, \mathrm{Cl}^{\prime}\right), 202\left(\mathrm{~W}(\mathrm{CO})_{5}\right.$, trans $), 197$ (W(CO) $)_{5}$, cis), 158 (C2, C9), 143 (C3, C8), 127 (C4, C7)), 146 (C5, C6), $69\left(\mathrm{COCH}_{3}\right)$ - IR (hexane, $\left.\mathrm{cm}^{-1}\right): v_{\mathrm{CO}}=2064(\mathrm{~m}), 1981(\mathrm{vw})$, 1957 (s), 1947 (vs).

7. Yield $1.36 \mathrm{~g}$ (method $1,1.4 \mathrm{mmol}, 28 \%$ ) or $0.49 \mathrm{~g}$ (method 2, $0.5 \mathrm{mmol}, 10 \%)$. Anal. calcd for $\mathrm{C}_{15} \mathrm{H}_{8} \mathrm{O}_{6} \mathrm{~S}_{2} \mathrm{~W}$ (970.263): $\mathrm{C}$ 32.19, H 1.87; Found: C 32.44, H 1.98 - MS (EI): $m / z$ (based on $\left.{ }^{184} \mathrm{~W}\right)[\mathrm{M}]^{+}$not observed. $-{ }^{1} \mathrm{H}$ NMR $\left(\mathrm{CDCl}_{3}, \mathrm{ppm}\right): \delta 8.07$ (d, H3, 4.4 Hz), 7.46 (d, H4, 4.4 Hz), 7.47 (d, H7, 4.4 Hz), 8.08 (d, H8, $4.4 \mathrm{~Hz}), 4.65\left(\mathrm{~s}, \mathrm{OCH}_{3}\right), 4.94\left(\mathrm{t}, \mathrm{COCH}_{2}, 6.3 \mathrm{~Hz}\right), 2.06-$ $2.15\left(\mathrm{~m}, \mathrm{OCH}_{2} \mathrm{CH}_{2}\right), 1.79-1.88\left(\mathrm{~m}, \mathrm{CH}_{2} \mathrm{CH}_{2} \mathrm{CH}_{2} \mathrm{CH}_{2} \mathrm{O}\right), 3.49(\mathrm{t}$, $\left.\mathrm{CH}_{2} \mathrm{CH}_{2} \mathrm{CH}_{2} \mathrm{CH}_{2} \mathrm{O}, 6.1 \mathrm{~Hz}\right), 3.36\left(\mathrm{~s}, \mathrm{CH}_{2} \mathrm{CH}_{2} \mathrm{OCH}_{3}\right){ }^{-13} \mathrm{C} \mathrm{NMR}^{-1}$ $\left(\mathrm{CDCl}_{3}, \mathrm{ppm}\right): \delta 291(\mathrm{C} 1), 289\left(\mathrm{Cl}^{\prime}\right), 203,202\left(\mathrm{~W}(\mathrm{CO})_{5}\right.$, trans $)$, 197 (2x) (W(CO) 5 , cis), 158 (C2), 143 (C3), 127 (C4), 145 (C5), 146 (C6), 127 (C7), 143 (C8), 158 (C9), 68 (OMe), 82, 72, (OCH ), 27, $26\left(\mathrm{OCH}_{2} \mathrm{CH}_{2} \mathrm{CH}_{2} \mathrm{CH}_{2} \mathrm{O}\right), 59\left(\mathrm{OCH}_{3}\right)$ - IR (hexane, $\left.\mathrm{cm}^{-1}\right): v_{\mathrm{CO}}=$ 2064 (m), 1982 (vw), 1955 (s), 1946 (vs).

8. Yield $0.89 \mathrm{~g}$ (method $1,0.85 \mathrm{mmol}, 17 \%)$ or $0.36 \mathrm{~g}$ (method 2 , $0.35 \mathrm{mmol}, 7 \%$ ). Anal. calcd for $\mathrm{C}_{30} \mathrm{H}_{26} \mathrm{O}_{14} \mathrm{~S}_{2} \mathrm{~W}_{2}$ (1042.4): C 34.57, H 1.55; Found: C 34.73, H 1.68 - MS (EI): $m / z$ (based on ${ }^{184} \mathrm{~W}$ ) $[\mathrm{M}]^{+}$not observed. ${ }^{1} \mathrm{H}$ NMR $\left(\mathrm{CDCl}_{3}, \mathrm{ppm}\right): \delta 8.08(\mathrm{~d}, \mathrm{H} 3, \mathrm{H} 8$, $4.4 \mathrm{~Hz}), 7.46$ (d, H4, H7, $4.4 \mathrm{~Hz}), 4.94$ (t, $\left.\mathrm{COCH}_{2}, 6.5 \mathrm{~Hz}\right), 2.06-$ $2.15\left(\mathrm{~m}, \mathrm{OCH}_{2} \mathrm{CH}_{2}\right), 1.79-1.88\left(\mathrm{~m}, \mathrm{CH}_{2} \mathrm{CH}_{2} \mathrm{CH}_{2} \mathrm{CH}_{2} \mathrm{O}\right), 3.49$ (t, $\left.\mathrm{CH}_{2} \mathrm{CH}_{2} \mathrm{CH}_{2} \mathrm{CH}_{2} \mathrm{O}, 6.2 \mathrm{~Hz}\right), 3.35\left(\mathrm{~s}, \mathrm{CH}_{2} \mathrm{CH}_{2} \mathrm{OCH}_{3}\right){ }^{13} \mathrm{C} \mathrm{NMR}$ $\left(\mathrm{CDCl}_{3}, \mathrm{ppm}\right): \delta 289(\mathrm{C} 1), 203\left(\mathrm{~W}(\mathrm{CO})_{5}\right.$, trans $), 197\left(\mathrm{~W}(\mathrm{CO})_{5}\right.$, cis), 158 (C2, C9), 143 (C3, C8), 127 (C4, C7), 145 (C5, C6), 82, 72, $\left(\mathrm{OCH}_{2}\right), 26\left(2 \mathrm{x} \mathrm{OCH}_{2} \mathrm{CH}_{2} \mathrm{CH}_{2} \mathrm{CH}_{2} \mathrm{O}\right), 59\left(\mathrm{OCH}_{3}\right)-\mathrm{IR}$ (hexane, $\mathrm{cm}^{-1}$ ): $v_{\mathrm{CO}}=2063(\mathrm{~m}), 1980(\mathrm{vw}), 1954(\mathrm{~s}), 1946(\mathrm{vs})$.

Synthesis of $\left[\mathrm{Cr}(\mathrm{CO})_{5}\{\mathrm{C}(\mathrm{OMe}) \mathrm{Th}-\mathrm{ThH}\}\right], \quad(1)\left[(\mathrm{CO})_{5} \mathrm{Cr}-\right.$ $\left.\{\mathrm{C}(\mathrm{OMe}) \mathrm{Th}-\mathrm{ThC}(\mathrm{OMe})\} \mathrm{Cr}(\mathrm{CO})_{5}\right] \quad(3), \quad$ I(CO) $)_{5} \mathrm{Cr}\{\mathrm{C}(\mathrm{OMe}) \mathrm{Th}-$ $\left.\mathrm{ThC}\left(\mathrm{O}\left(\mathrm{CH}_{2}\right)_{4} \mathrm{OMe}\right)\right\} \mathrm{Cr}(\mathrm{CO})_{5}$ ] (6). The same procedure described above was followed using chromium hexacarbonyl instead of tungsten hexacarbonyl.

\section{Characterization of products}

1. Yield $0.46 \mathrm{~g}$ (method 2, $1.15 \mathrm{mmol}, 23 \%$ ). Anal. calcd for $\mathrm{C}_{15} \mathrm{H}_{8} \mathrm{O}_{6} \mathrm{~S}_{2} \mathrm{Cr}$ (400.3): C 45.01, H 2.01; Found: C 45.27, H 2.19 MS (EI): $m / z \quad 400[\mathrm{M}]^{+}$, stepwise fragmentation of carbonyl ligands, $260\left([\mathrm{M}]^{+}-5 \mathrm{CO}\right) .-{ }^{1} \mathrm{H}$ NMR $\left(\mathrm{CDCl}_{3}, \mathrm{ppm}\right): \delta 8.18(\mathrm{~d}$, H3, $4.4 \mathrm{~Hz}$ ), 7.29 (d, H4, 4.4 Hz), 7.37 (d, H7, 5.2 Hz), 7.07 (dd, H8, 5.2, 3.6 Hz), 7.38 (br-dd, H9, $3.6 \mathrm{~Hz}$ ), 4.79 (s, $\mathrm{COCH}_{3}$ ). $-{ }^{13} \mathrm{C} \mathrm{NMR}\left(\mathrm{CDCl}_{3}, \mathrm{ppm}\right): \delta 314(\mathrm{C} 1), 223\left(\mathrm{Cr}(\mathrm{CO})_{5}\right.$, trans $), 217$ $\left(\mathrm{Cr}(\mathrm{CO})_{5}\right.$, cis $), 152$ (C2), 143 (C3), 125 (C4), 147 (C5), 136 (C6), 
128 (C7), 129 (C8), 126 (C9), $66\left(\mathrm{COCH}_{3}\right)$ - IR (hexane, $\left.\mathrm{cm}^{-1}\right)$ : $v_{\mathrm{CO}}=2058(\mathrm{~m}), 1982(\mathrm{vw}), 1957(\mathrm{~s}), 1947(\mathrm{vs})$.

3. Yield $1.05 \mathrm{~g}$ (method 2, $1.65 \mathrm{mmol}, 33 \%$ ). Anal. calcd for $\mathrm{C}_{22} \mathrm{H}_{10} \mathrm{O}_{12} \mathrm{~S}_{2} \mathrm{Cr}_{2}$ : C 41.65, H 1.59; Found: C 41.93, H 1.76 - MS (EI): $m / z 634[\mathrm{M}]^{+}$stepwise fragmentation of carbonyl ligands, $354[\mathrm{M}-10 \mathrm{CO}]^{+}-{ }^{1} \mathrm{H}$ NMR $\left(\mathrm{CDCl}_{3}, \mathrm{ppm}\right): \delta 8.17$ (d, H3/H8, $4.4 \mathrm{~Hz}), 7.45$ (d, H4/H7, $4.4 \mathrm{~Hz}), 4.83\left(\mathrm{~s}, \mathrm{COCH}_{3}\right) .{ }^{13} \mathrm{C} \mathrm{NMR}$ $\left(\mathrm{CDCl}_{3}, \mathrm{ppm}\right): \delta 316(\mathrm{C} 1), 223\left(\mathrm{Cr}(\mathrm{CO})_{5}\right.$, trans $), 217\left(\mathrm{Cr}(\mathrm{CO})_{5}\right.$, cis), 154 (C2, C9), 142 (C3, C8), 127 (C4, C7), 144 (C5, C6), 66 $\left(\mathrm{COCH}_{3}\right)$ - IR (hexane, $\left.\mathrm{cm}^{-1}\right): v_{\mathrm{CO}}=2054(\mathrm{~m}), 1985(\mathrm{vw}), 1962$ (s), 1951 (vs).

6. Yield $0.35 \mathrm{~g}$ (method 2, $0.5 \mathrm{mmol}, 10 \%$ ). Anal. calcd for $\mathrm{C}_{26} \mathrm{H}_{18} \mathrm{O}_{13} \mathrm{~S}_{2} \mathrm{Cr}_{2}$ (706.6): C 33.86, H 1.51; Found: C 34.03, H 1.68 MS (EI): $m / z 706[\mathrm{M}]^{+}$stepwise fragmentation of carbonyl ligands, $426\left[\mathrm{M}-10 \mathrm{CO}^{+}{ }^{+}{ }^{1} \mathrm{H} \mathrm{NMR}\left(\mathrm{CDCl}_{3}, \mathrm{ppm}\right): \delta 8.16(\mathrm{~d}\right.$, H3, 4.4 Hz), 7.45 (d, H4, 4.4 Hz), 7.46 (d, H7, 4.4 Hz), 8.17 (d, $\mathrm{H} 8,4.4 \mathrm{~Hz}), 4.83\left(\mathrm{~s}, \mathrm{OCH}_{3}\right), 5.13\left(\mathrm{t}, \mathrm{COCH}_{2}, 6.3 \mathrm{~Hz}\right), 2.07-2.70$ (m, $\mathrm{OCH}_{2} \mathrm{CH}_{2} \mathrm{CH}_{2}$ ), 1.80-1.89 (m, $\left.\mathrm{CH}_{2} \mathrm{CH}_{2} \mathrm{CH}_{2} \mathrm{CH}_{2} \mathrm{O}\right), 3.49$ (t, $\left.\mathrm{CH}_{2} \mathrm{CH}_{2} \mathrm{O}, 6.1 \mathrm{~Hz}\right), 3.36\left(\mathrm{~s}, \mathrm{CH}_{2} \mathrm{OCH}_{3}\right){ }^{-13} \mathrm{C} \mathrm{NMR}\left(\mathrm{CDCl}_{3}, \mathrm{ppm}\right)$ : $\delta 316(\mathrm{C} 1), 314\left(\mathrm{Cl}^{\prime}\right), 223(2 \mathrm{x})\left(\mathrm{Cr}(\mathrm{CO})_{5}\right.$, trans $), 217(2 \mathrm{x})\left(\mathrm{Cr}(\mathrm{CO})_{5}\right.$, cis), 154 (C2), 142 (C3), 127 (C4), 144 (C5), 144 (C6), 127 (C7), 142 (C8), 154 (C9), $66\left(\mathrm{OCH}_{3}\right), 80,72,\left(\mathrm{OCH}_{2}\right), 27,26$ $\left(\mathrm{OCH}_{2} \mathrm{CH}_{2} \mathrm{CH}_{2} \mathrm{CH}_{2} \mathrm{O}\right), 59\left(\mathrm{OCH}_{3}\right)$ - IR (hexane, $\left.\mathrm{cm}^{-1}\right): v_{\mathrm{CO}}=$ 2056 (m), 1986 (vw), 1955 (s), 1951 (vs).

Synthesis of $\left[\mathrm{Cr}(\mathrm{CO})_{5}\{\mathrm{C}(\mathrm{OMe}) \mathrm{Th}-\mathrm{ThC}(\mathrm{OMe})\} \mathrm{W}(\mathrm{CO})_{5}\right]$ (5). $0.33 \mathrm{~g}(2.0 \mathrm{mmol})$ of bithiophene was dissolved in $10 \mathrm{~mL}$ of THF and $1.25 \mathrm{~mL}(2 \mathrm{mmol})$ of $n-\mathrm{BuLi}$ in a $1.6 \mathrm{M}$ hexane solution was added at $-10{ }^{\circ} \mathrm{C}$ and the reaction was stirred for 30 minutes. The mixture was cooled to $-40{ }^{\circ} \mathrm{C}$ and $0.44 \mathrm{~g}(2.0 \mathrm{mmol})$ of $\mathrm{Cr}(\mathrm{CO})_{6}$ was added in small portions. After $15 \mathrm{~min}$ stirring, the solution was removed from the cold bath and stirred for a further 15 min during which the colour of the reaction mixture changed to red-brown. The reaction mixture was cooled to $-78^{\circ} \mathrm{C}$ and a THF solution $(10 \mathrm{~mL})$ containing $2.4 \mathrm{mmol}$ of LDA (prepared according to Brandsma ${ }^{34}$ ), was added. Stirring was maintained at this temperature for $1 \mathrm{~h}$ after which the reaction was warmed to $-40{ }^{\circ} \mathrm{C} .0 .70 \mathrm{~g}(2.0 \mathrm{mmol})$ of $\mathrm{W}(\mathrm{CO})_{6}$ was added in small portions where after the temperature was allowed to rise to room temperature. The colour of the reaction mixture changed to dark brown. The solvent was removed in vacuo, the reaction residue was dissolved in $10 \mathrm{~mL}$ of dichloromethane and cooled to $-20{ }^{\circ} \mathrm{C}$. Dissolved in $10 \mathrm{~mL}$ of dichloromethane, $2.28 \mathrm{~mL}$ methyl trifluoromethanesulfonate $(20 \mathrm{mmol})$ was added. An immediate colour change to dark purple was observed. The cooling bath was removed and stirring was continued for a further hour. The mixture was washed with dichloromethane through a filter containing a silica gel plug. The solvent was removed in vacuo and the remainder purified on a silica gel column. In addition to $\mathbf{5}$, other products isolated were $\mathbf{1}(5 \%)$ and $\mathbf{2}(8 \%)$ after starting with hexane as eluting agent and increasing the polarity gradually by adding dichloromethane.

\section{Characterization of products}

5. Yield $0.37 \mathrm{~g}(0.48 \mathrm{mmol}, 12 \%)$. Anal. calcd for $\mathrm{C}_{26} \mathrm{H}_{18} \mathrm{O}_{13} \mathrm{~S}_{2} \mathrm{Cr}_{2}$ (706.6): C 44.20, H 2.57; Found: C 44.43, H 2.78 MS (EI): $m / z[\mathrm{M}]^{+}$not observed- ${ }^{1} \mathrm{H} \mathrm{NMR}\left(\mathrm{CDCl}_{3}, \mathrm{ppm}\right): \delta 8.16$ (d, H3, 4.4 Hz), 7.44 (d, H4, 4.4 Hz), 7.46 (d, H7, 4.4 Hz), 8.08 (d, H8, 4.4, $3.6 \mathrm{~Hz}), 4.83\left(\mathrm{~s}, \mathrm{CrCOCH}_{3}\right), 4.65$ (s, $\left.\mathrm{WCOCH}_{3}\right) \cdot{ }^{13} \mathrm{C}$ NMR (CDCl, ppm): $\delta 317(\mathrm{C} 1(\mathrm{Cr})), 291\left(\mathrm{Cl}^{\prime}(\mathrm{W})\right), 223\left(\mathrm{Cr}(\mathrm{CO})_{5}\right.$, trans), $217\left(\mathrm{Cr}(\mathrm{CO})_{5}\right.$, cis $), 202\left(\mathrm{~W}(\mathrm{CO})_{5}\right.$, trans $), 197\left(\mathrm{~W}(\mathrm{CO})_{5}\right.$, cis $)$, 154 (C2), 142 (C3), 127 (C4), 146, 145 (C5, C6), 127 (C7), 143 (C8), $158(\mathrm{C} 9), 69\left(\mathrm{~W}-\mathrm{OCH}_{3}\right), 66\left(\mathrm{Cr}-\mathrm{OCH}_{3}\right)$ - IR (hexane, $\left.\mathrm{cm}^{-1}\right)$ : $v_{\mathrm{CO}}=2062,2056(\mathrm{~m}), 1983(\mathrm{vw}), 1957(\mathrm{~s}), 1948(\mathrm{vs})$.

\section{Synthesis of metal carbene complexes from \\ N,N'-Dimethylbipyrrole(HPyr-PyrH)}

Synthesis of $\left[\mathrm{Cr}(\mathrm{CO})_{5}\{\mathrm{C}(\mathrm{OEt}) \mathrm{Pyr}-\mathrm{PyrH}\}\right](9)$ and $\left[(\mathrm{CO})_{5} \mathrm{Cr}-\right.$ $\{\mathbf{C}(\mathbf{O E t})$ Pyr-PyrC(OEt) $\} \mathbf{C r}(\mathbf{C O})_{5}$ l (11). To $0.24 \mathrm{~g}(1.50 \mathrm{mmol})$ $\mathrm{N}, \mathrm{N}^{\prime}$-dimethylbipyrrole dissolved in $10 \mathrm{~mL}$ hexane was added $0.36 \mathrm{~g}$ TMEDA $(0.47 \mathrm{~mL} ; 3.1 \mathrm{mmol})$. After cooling to $0{ }^{\circ} \mathrm{C}$, $2.0 \mathrm{~mL}(3.2 \mathrm{mmol})$ of a $1.60 \mathrm{M}$ solution of $n$-BuLi in hexane was added. After stirring for 10 minutes the ice bath was removed and the reaction mixture warmed to room temperature. The colour of the solution was yellow. The temperature of the reaction mixture was increased to near the boiling point of hexane, and left for 15 minutes, after which the mixture was allowed to cool down to room temperature again.

The mixture was first cooled to $-40{ }^{\circ} \mathrm{C}$ and $0.66 \mathrm{~g}(3 \mathrm{mmol})$ $\mathrm{Cr}(\mathrm{CO})_{6}$ was added in small portions and the mixture stirred for $30 \mathrm{~min}$. Afterwards the solution was warmed to room temperature and stirring was continued for $1 \mathrm{~h}$. The colour of the solution became dark red-brown. The solvent was removed, a little dichloromethane was added to dissolve the residue, and the solution was again cooled $\left(-30^{\circ} \mathrm{C}\right) .0 .60 \mathrm{~g}(3.1 \mathrm{mmol}) \mathrm{Et}_{3} \mathrm{OBF}_{4}$, dissolved beforehand in $10 \mathrm{~mL}$ dichloromethane, was added. The reaction mixture was stirred in the cold for $30 \mathrm{~min}$ and for a further $30 \mathrm{~min}$ at room temperature. The solvent was removed under reduced pressure. The residue was purified by column chromatography with silica gel as stationary phase. Two products were obtained after eluting with a hexane: dichloromethane $(4: 1)$ mixture and collecting and purifying the dark zones to give 9 and 11.

\section{Characterization of products}

9. Yield $0.18 \mathrm{~g}(0.43 \mathrm{mmol}, 29 \%)$ Anal. calcd for $\mathrm{C}_{15} \mathrm{H}_{8} \mathrm{O}_{7} \mathrm{~N}_{2} \mathrm{Cr}$ (407.3) C 53.08, H 3.71, N 6.89; Found: C 53.23, H 3.86, N 6.68 MS (EI): $m / z 408[\mathrm{M}]^{+}$, stepwise fragmentation by loss of carbonyl ligands, $268\left([\mathrm{M}]^{+}-5 \mathrm{CO}\right) .-{ }^{1} \mathrm{H}$ NMR $\left(\mathrm{CDCl}_{3}, \mathrm{ppm}\right): \delta 7.75(\mathrm{~d}, \mathrm{H} 3$, $4.7 \mathrm{~Hz}), 6.33$ (d, H4, $4.7 \mathrm{~Hz}), 6.14(\mathrm{dd}, \mathrm{H} 7,3.6,1.8 \mathrm{~Hz}), 6.17$ (dd, H8, 3.6, 2.7 Hz), 6.70 (dd, H9, 2.7, $1.8 \mathrm{~Hz}$ ), 5.08 (q, $\mathrm{OCH}_{2}$, $7.1 \mathrm{~Hz}), 1.64\left(\mathrm{t}, \mathrm{OCH}_{2} \mathrm{CH}_{3}, 7.0 \mathrm{~Hz}\right), 3.49$ (2 signals, $\left.\mathrm{NCH}_{3}\right)$. ${ }^{13} \mathrm{C} \mathrm{NMR}\left(\mathrm{CDCl}_{3}, \mathrm{ppm}\right): \delta 330(\mathrm{C} 1), 223\left(\mathrm{Cr}(\mathrm{CO})_{5}\right.$, trans $), 218$ $\left(\mathrm{Cr}(\mathrm{CO})_{5}\right.$, cis), 134 (C2), 125 (C3), 113 (C4), 123 (C5), 111 (C6), 109 (C7), 107 (C8), 114 (C9), $77\left(\mathrm{OCH}_{2}\right), 15.6\left(\mathrm{OCH}_{2} \mathrm{CH}_{3}\right), 38$ (2 signals, $\mathrm{NCH}_{3}$ ) - IR (hexane, $\mathrm{cm}^{-1}$ ): $v_{\mathrm{CO}}=2054(\mathrm{~m}), 1943$ (s), 1934 (vs).

11. Yield $0.32 \mathrm{~g}(0.48 \mathrm{mmol}, 32 \%)$. Anal. calcd for $\mathrm{C}_{26} \mathrm{H}_{20} \mathrm{O}_{12} \mathrm{~N}_{2} \mathrm{Cr}_{2}$ (560.5): C 47.57, H 3.07, N 4.27; Found: C 47.71, $\mathrm{H} 3.18, \mathrm{~N} 4.04$ - MS (EI): $m / z[\mathrm{M}]^{+}$not observed.- ${ }^{1} \mathrm{H}$ NMR $\left(\mathrm{CDCl}_{3}, \mathrm{ppm}\right): \delta 7.73(\mathrm{~d}, \mathrm{H} 3 / \mathrm{H} 8,4.4 \mathrm{~Hz}), 6.38 / 6.33(\mathrm{~d}, \mathrm{H} 4 / \mathrm{H} 7$, $4.4 \mathrm{~Hz}$ ), 5.14 (q, $\left.\mathrm{OCH}_{2}, 7.1 \mathrm{~Hz}\right), 1.67\left(\mathrm{t}, \mathrm{OCH}_{2} \mathrm{CH}_{3}, 7.1 \mathrm{~Hz}\right), 3.60$, 3.56 (2 signals, $\left.\mathrm{NCH}_{3}\right) .{ }^{13} \mathrm{C} \mathrm{NMR}\left(\mathrm{CDCl}_{3}, \mathrm{ppm}\right): \delta 327(\mathrm{C} 1)$, $225\left(\mathrm{Cr}(\mathrm{CO})_{5}\right.$, trans $), 218\left(\mathrm{Cr}(\mathrm{CO})_{5}\right.$, cis $), 157$ (C2, C9), $134(\mathrm{C} 3$, 
C8), 115 (C4, C7), 145 (C5, C6), $79\left(\mathrm{OCH}_{2}\right), 15\left(\mathrm{OCH}_{2} \mathrm{CH}_{3}\right), 38$ $\left(\mathrm{NCH}_{3}\right.$ ) - IR (hexane, $\mathrm{cm}^{-1}$ ): $v_{\mathrm{CO}}=2054$ (m), 1943 (s), 1934 (vs).

Synthesis of $\left[\mathrm{W}(\mathrm{CO})_{5}\{\mathrm{C}(\mathrm{OEt}) \mathrm{Pyr}-\mathrm{PyrH}\}\right](\mathbf{1 0})$ and $\left[(\mathrm{CO})_{5^{-}}\right.$ $\left.\mathbf{W}\{\mathbf{C}(\mathrm{OEt}) \operatorname{Pyr}-\mathbf{P y r C}(\mathbf{O E t})\} \mathbf{W}(\mathbf{C O})_{5}\right]$ (12). The same procedure described above was followed using tungsten hexacarbonyl instead of chromium hexacarbonyl.

\section{Characterization of products}

10. Yield $0.23 \mathrm{~g}(0.42 \mathrm{mmol}, 28 \%)$. Anal. calcd for $\mathrm{C}_{18} \mathrm{H}_{15} \mathrm{O}_{6} \mathrm{~N}_{2} \mathrm{~W}$ (539.2): C 40.10, H 2.80, N 5.20; Found: C 40.23, $\mathrm{N} 5.13$ - MS (EI): $\mathrm{m} / \mathrm{z}$ (based on ${ }^{184} \mathrm{~W}$ ) $540[\mathrm{M}]^{+}$, stepwise fragmentation by loss of carbonyl ligands, $400\left([\mathrm{M}]^{+}-5 \mathrm{CO}\right) \cdot-{ }^{1} \mathrm{H}$ NMR (CDCl 3 , ppm): $\delta 7.71(\mathrm{~d}, \mathrm{H} 3,4.4 \mathrm{~Hz}), 6.33(\mathrm{~d}, \mathrm{H} 4,4.7 \mathrm{~Hz})$, 6.23 (dd, H7, 3.6, 1.8 Hz), 6.26 (dd, H8, 3.8, 2.7 Hz), 6.79 (dd, H9, 2.7, $1.8 \mathrm{~Hz}), 4.92\left(\mathrm{q}, \mathrm{OCH}_{2}, 7.1 \mathrm{~Hz}\right), 3.65,3.57\left(\mathrm{~s}, \mathrm{NCH}_{3}\right), 1.62$ (t, $\left.\mathrm{OCH}_{2} \mathrm{CH}_{3}, 7.1 \mathrm{~Hz}\right) .-{ }^{13} \mathrm{C} \mathrm{NMR}\left(\mathrm{CDCl}_{3}, \mathrm{ppm}\right): \delta 288(\mathrm{C} 1), 202$ $\left(\mathrm{W}(\mathrm{CO})_{5}\right.$, trans $), 198\left(\mathrm{~W}(\mathrm{CO})_{5}\right.$, cis $), 137(\mathrm{C} 2), 136(\mathrm{C} 3), 115(\mathrm{C} 4)$, 134 (C5), 114 (C6), 113 (C7), 108 (C8), 125 (C9), 75 ( $\left.\mathrm{OCH}_{2}\right), 37.8$ (2x) $\left.\mathrm{NCH}_{3}\right), 16\left(\mathrm{OCH}_{2} \mathrm{CH}_{3}\right)$. - IR (hexane, $\left.\mathrm{cm}^{-1}\right): v_{\mathrm{CO}}=2062(\mathrm{~m})$, 1971 (vw), 1944 (s), 1934 (vs).

12. Yield $0.47 \mathrm{~g}(0.51 \mathrm{mmol}, 34 \%)$ Anal. calcd for $\mathrm{C}_{26} \mathrm{H}_{20} \mathrm{O}_{12} \mathrm{~N}_{2} \mathrm{~W}_{2}$ (920.2): C 33.94, H 2.19, N 3.04; Found: $\mathrm{C} 34.03$, $\mathrm{H} 2.28$, N 2.88 - MS (EI): $m / z$ (based on ${ }^{184} \mathrm{~W}$ ) [M] ${ }^{+}$not observed. - ${ }^{1} \mathrm{H}$ NMR $\left(\mathrm{CDCl}_{3}, \mathrm{ppm}\right): \delta 7.69(\mathrm{~d}, \mathrm{H} 3 / \mathrm{H} 8,4.4 \mathrm{~Hz}), 6.39(\mathrm{~d}$, $\mathrm{H} 4 / \mathrm{H} 7,4.4 \mathrm{~Hz}$ ), 4.98 (q, $\mathrm{OCH}_{2} \mathrm{CH}_{3}, 7.1 \mathrm{~Hz}$ ), $3.62\left(\mathrm{~s}, \mathrm{NCH}_{3}\right), 1.65$ (t, $\left.\mathrm{OCH}_{2} \mathrm{CH}_{3}, 7.1 \mathrm{~Hz}\right) .-{ }^{13} \mathrm{C} \mathrm{NMR}\left(\mathrm{CDCl}_{3}, \mathrm{ppm}\right): \delta 282(\mathrm{C} 1), 202$ $\left(\mathrm{W}(\mathrm{CO})_{5}\right.$, trans $), 198\left(\mathrm{~W}(\mathrm{CO})_{5}\right.$, cis $), 148(\mathrm{C} 2, \mathrm{C} 9), 135$ (C3, C8), $115(\mathrm{C} 4, \mathrm{C} 7)), 137(\mathrm{C} 5, \mathrm{C} 6), 79\left(\mathrm{OCH}_{2} \mathrm{CH}_{3}\right), 15\left(\mathrm{OCH}_{2} \mathrm{CH}_{3}\right)$ - IR (hexane, $\mathrm{cm}^{-1}$ ): $v_{\mathrm{CO}}=2062(\mathrm{~m}), 1970(\mathrm{vw}), 1944$ (s), 1933 (vs).

\section{Synthesis of metal carbene complexes from thienylfuran(HTh-FuH)}

Synthesis of $\left[\mathrm{Cr}(\mathrm{CO})_{5}\{\mathrm{C}(\mathrm{OMe}) \mathrm{Th}-\mathrm{FuH}\}\right](\mathrm{13})$ and $\left[(\mathrm{CO})_{5} \mathrm{Cr}-\right.$ $\left.\{\mathrm{C}(\mathrm{OMe}) \mathrm{Th}-\mathrm{FuC}(\mathrm{OMe})\} \mathbf{C r}(\mathrm{CO})_{5}\right]$ (15). A THF solution $(30 \mathrm{~mL})$ containing $0.75 \mathrm{~g}(5.0 \mathrm{mmol}) 2,2^{\prime}$-thienylfuran was cooled to $-20^{\circ} \mathrm{C}$ and $6.88 \mathrm{~mL}(11 \mathrm{mmol})$ of a $1.6 \mathrm{M}$ solution of $n$-BuLi in hexane was added. The reaction mixture was stirred for 30 minutes and the temperature of the cold bath was lowered to $-40{ }^{\circ} \mathrm{C}$. Small solid portions of $\mathrm{Cr}(\mathrm{CO})_{6}(2.64 \mathrm{~g}, 10.2 \mathrm{mmol})$ was slowly added and the mixture stirred for 30 minutes. The cold bath was removed and the brown reaction mixture stirred at room temperature for $1 \mathrm{~h}$. The reaction mixture was cooled to $-20{ }^{\circ} \mathrm{C}$ and $3.40 \mathrm{~mL}(30 \mathrm{mmol})$ methyl trifluoromethanesulfonate was added and the mixture stirred for $30 \mathrm{~min}$ in the cold and thereafter for $30 \mathrm{~min}$ at room temperature. The solvent was removed under reduced pressure after the alkylation was completed. The residue was absorbed on silica gel and placed on a silica gel column. The complexes 13 and 15 were collected after eluting with a hexane: dichloromethane mixture $(4: 1)$.

\section{Characterization of products}

13. Yield $0.33 \mathrm{~g}(0.85 \mathrm{mmol}, 17 \%)$. Anal. calcd for $\mathrm{C}_{15} \mathrm{H}_{8} \mathrm{O}_{7} \mathrm{SCr}$ (384.3): C 46.89, H 2.10; Found: C 47.03, H 2.18 -MS (EI): $m / z$ $384[\mathrm{M}]^{+}$, stepwise fragmentation of carbonyl ligands, $392\left([\mathrm{M}]^{+}-\right.$ 5CO).- ${ }^{1} \mathrm{H}$ NMR $\left(\mathrm{CDCl}_{3}, \mathrm{ppm}\right): \delta 8.19(\mathrm{~d}, \mathrm{H} 3,4.4 \mathrm{~Hz}), 7.34(\mathrm{~d}$, H4, 4.4 Hz), 6.78 (d, H7, 3.6 Hz), 6.50 (dd, H8, 3.6, 1.8 Hz), 7.49 (dd, H9, $1.8 \mathrm{~Hz}), 4.79$ (s, $\left.\mathrm{OCH}_{3}\right) .{ }^{13} \mathrm{C} \mathrm{NMR}\left(\mathrm{CDCl}_{3}, \mathrm{ppm}\right): \delta 314$ (C1), $223\left(\mathrm{Cr}(\mathrm{CO})_{5}\right.$, trans), $217\left(\mathrm{Cr}(\mathrm{CO})_{5}\right.$, cis $), 152(\mathrm{C} 2), 143(\mathrm{C} 3)$, 124 (C4), 145 (C5), 148 (C6), 110 (C7), 113 (C8), 144 (C9), 66 $\left(\mathrm{OCH}_{3}\right)$ - IR (hexane, $\left.\mathrm{cm}^{-1}\right): v_{\mathrm{CO}}=2058(\mathrm{~m}), 1986(\mathrm{vw}), 1957(\mathrm{~s})$, 1947 (vs).

15. Yield $0.80 \mathrm{~g}(1.30 \mathrm{mmol}, 26 \%)$. Anal. calcd for $\mathrm{C}_{22} \mathrm{H}_{10} \mathrm{O}_{13} \mathrm{SCr}_{2}$ (618.4): C 42.73, H 1.63; Found: C 42.88, H 1.78 MS (EI): $m / z 618[\mathrm{M}]^{+}$stepwise fragmentation of 10 carbonyl ligands, 338 ([M+]-10CO).- ${ }^{1} \mathrm{H}$ NMR $\left(\mathrm{CDCl}_{3}, \mathrm{ppm}\right): \delta 8.17(\mathrm{~d}$, H3, $4.4 \mathrm{~Hz}$ ), 7.45 (d, H4, $4.4 \mathrm{~Hz}), 6.89$ (d, H7, $3.9 \mathrm{~Hz}), 6.94$, $(\mathrm{d}, \mathrm{H} 8,3.9 \mathrm{~Hz}), 4.88\left(\mathrm{~s}, \mathrm{O}-\mathrm{OCH} \mathrm{CH}_{3}\right), 4.83\left(\mathrm{~s}, \mathrm{~S}-\mathrm{OCH} \mathrm{H}_{3}\right) \cdot{ }^{13} \mathrm{C} \mathrm{NMR}$ $\left(\mathrm{CDCl}_{3}, \mathrm{ppm}\right): \delta 317$ (2 signals, $\left.\mathrm{C1}, \mathrm{Cl}^{\prime}\right), 224,223\left(\mathrm{Cr}(\mathrm{CO})_{5}\right.$, trans), 217 (2 signals, $\mathrm{Cr}(\mathrm{CO})_{5}$, cis), $156(\mathrm{C} 2), 142$ (C3), 127 (C4), 144 (C5), 154 (C6), 112 (C7), 112 (C8), 163 (C9), 66 (2 signals, OMe). - IR (hexane, $\mathrm{cm}^{-1}$ ): $v_{\mathrm{CO}}=2056(\mathrm{~m}), 1990$ (vw), 1962 (s), 1951 (vs).

Synthesis of $\left[\mathrm{W}(\mathrm{CO})_{5}\{\mathrm{C}(\mathrm{OMe}) \mathrm{Th}-\mathrm{FuH}\}\right]$ (14) and $\left[(\mathrm{CO})_{5^{-}}\right.$ $\left.\mathbf{W}\{\mathrm{C}(\mathrm{OMe}) \mathrm{Th}-\mathrm{FuC}(\mathrm{OMe})\} \mathbf{W}(\mathbf{C O})_{5}\right]$ (16). The same procedure described above was followed using tungsten hexacarbonyl instead of chromium hexacarbonyl.

\section{Characterization of products}

14. Yield $0.44 \mathrm{~g}(0.85 \mathrm{mmol}, 17 \%)$. Anal. calcd for $\mathrm{C}_{15} \mathrm{H}_{8} \mathrm{O}_{7} \mathrm{SW}$ (516.2): C 34.91, H 1.56; Found: C 35.03, H 1.68 - MS (EI): $\mathrm{m} / \mathrm{z}$ (based on ${ }^{184} \mathrm{~W}$ ) $516[\mathrm{M}]^{+}$, stepwise fragmentation by loss of carbonyl ligands, $376\left([\mathrm{M}]^{+}-5 \mathrm{CO}\right) .-{ }^{1} \mathrm{H} \mathrm{NMR}\left(\mathrm{CDCl}_{3}, \mathrm{ppm}\right): \delta 8.10$ (d, H3, 4.4 Hz), 7.33 (d, H4, 4.4 Hz), 6.81 (dd, H7, 3.4, $0.8 \mathrm{~Hz}), 6.51$ (dd, H8, 3.4, $1.8 \mathrm{~Hz}$ ), 7.51 (dd, H9, 1.8, $0.8 \mathrm{~Hz}$ ), 4.63 (s, $\mathrm{OCH}_{3}$ ). ${ }_{-}^{13} \mathrm{C} \mathrm{NMR}\left(\mathrm{CDCl}_{3}, \mathrm{ppm}\right): \delta 289(\mathrm{C} 1), 202\left(\mathrm{~W}(\mathrm{CO})_{5}\right.$, trans), 198 (W(CO) $\left.)_{5}, c i s\right), 155$ (C2), 144 (C3), 124 (C4), 144 (C5), 149 (C6), $110(\mathrm{C} 7), 113(\mathrm{C} 8), 143(\mathrm{C} 9), 68\left(\mathrm{OCH}_{3}\right)$ - IR (hexane, $\left.\mathrm{cm}^{-1}\right): v_{\mathrm{CO}}=$ 2065 (m), 1983 (vw), 1952 (s), 1944 (vs).

16. Yield $1.15 \mathrm{~g}(1.30 \mathrm{mmol}, 26 \%)$. Anal. calcd for $\mathrm{C}_{22} \mathrm{H}_{10} \mathrm{O}_{13} \mathrm{SW}_{2}$ (882.1): C 39.91, H 1.14; Found: C 40.13, H 1.18 MS (EI): $m / z$ (based on ${ }^{184} \mathrm{~W}$ ) $[\mathrm{M}]^{+}$not observed.- ${ }^{1} \mathrm{H}$ NMR $\left(\mathrm{CDCl}_{3}, \mathrm{ppm}\right): \delta 8.13(\mathrm{~d}, \mathrm{H} 3,4.4 \mathrm{~Hz}), 7.60(\mathrm{~d}, \mathrm{H} 4,4.4 \mathrm{~Hz}), 6.94$ (d, H7, $4.4 \mathrm{~Hz}), 7.12$ (d, H8, $4.4 \mathrm{~Hz}), 4.62$ (s, S-OCH $), 4.70$ (s, $\mathrm{O}-\mathrm{OCH}_{3}$ ). ${ }^{13} \mathrm{C} \mathrm{NMR}\left(\mathrm{CDCl}_{3}, \mathrm{ppm}\right): \delta 291,290(\mathrm{C} 1, \mathrm{C} 10), 204$, $203\left(\mathrm{~W}(\mathrm{CO})_{5}\right.$, trans $), 197$ (2 signals, $\mathrm{W}(\mathrm{CO})_{5}$, cis $), 158(\mathrm{C} 2), 143$ (C3), 127 (C4), 146 (C5), 156 (C6), 112 (C7), 114 (C8), 165 (C9), 69, $68\left(\mathrm{OCH}_{3}\right)$ - IR (hexane, $\left.\mathrm{cm}^{-1}\right): v_{\mathrm{CO}}=2065(\mathrm{~m}), 1983(\mathrm{vw})$, 1956 (s), 1946 (vs).

Synthesis of $\left[(\mathrm{CO})_{5} \mathrm{Cr}\{\mathrm{C}(\mathrm{OMe}) \mathrm{Th}-\mathrm{FuC}(\mathrm{OMe})\} \mathrm{W}(\mathrm{CO})_{5}\right]$ (17). $0.75 \mathrm{~g}(5.0 \mathrm{mmol})$ of 2,2'-thienylfuran was dissolved in $20 \mathrm{~mL}$ of THF and $3.44 \mathrm{~mL}(5.5 \mathrm{mmol})$ of a $1.60 \mathrm{M}$ solution of $n$ butyllithium in hexane was added at $-20{ }^{\circ} \mathrm{C}$ and the reaction was stirred for 30 minutes. $1.10 \mathrm{~g}(5.0 \mathrm{mmol})$ of $\mathrm{Cr}(\mathrm{CO})_{6}$ was added at $-40{ }^{\circ} \mathrm{C}$ in small portions where after the temperature was allowed to rise to room temperature. Stirring was maintained for a further $15 \mathrm{~min}$ during which the colour of the reaction mixture changed to red-brown. The reaction mixture was cooled to $-78{ }^{\circ} \mathrm{C}$ and a $\mathrm{THF}$ solution $(10 \mathrm{~mL})$ containing $6.0 \mathrm{mmol}$ of LDA (prepared according to Brandsma ${ }^{34}$ ) was added. Stirring was maintained at this temperature for $1 \mathrm{~h}$ after which the reaction was warmed to $-40^{\circ} \mathrm{C}$. $1.76 \mathrm{~g}(5.0 \mathrm{mmol})$ of $\mathrm{W}(\mathrm{CO})_{6}$ was added and the temperature was allowed to rise to room temperature. 
The colour of the reaction mixture usually changed to dark brown. The solvent was removed in vacuo, the reaction residue was dissolved in $20 \mathrm{~mL}$ of dichloromethane and cooled to $-20{ }^{\circ} \mathrm{C}$. $4.54 \mathrm{~mL}$ ( $40 \mathrm{mmol}$ ) of methyl trifluoromethanesulfonate in $10 \mathrm{~mL}$ of dichloromethane was added. An immediate colour change to dark purple was observed. The cooling bath was removed and stirring was continued for a further hour. The mixture was washed with dichloromethane through a filter containing a silica gel plug. The solvent was removed in vacuo and the residue adsorbed on silica gel and purified on a silica gel column. In addition to 17 , the complexes $1(23 \%), 3(13 \%)$ and $4(3 \%)$ were also isolated after starting with hexane as eluting agent and increasing the polarity gradually by adding dichloromethane to the eluting agent.

\section{Characterization of product}

17. Yield $0.49 \mathrm{~g} \quad(0.65 \mathrm{mmol}, 13 \%)$.Anal. calcd for $\mathrm{C}_{22} \mathrm{H}_{10} \mathrm{O}_{13} \mathrm{SWCr}$ (750.2): C 35.22, H 1.34; Found: C 35.43, H 1.48 MS (EI): $m / z$ [M] $]^{+}$not observed- ${ }^{1} \mathrm{H} \mathrm{NMR}\left(\mathrm{CDCl}_{3}, \mathrm{ppm}\right): \delta 8.22$ (d, H3, 4.4 Hz), 7.62 (d, H4, 4.4 Hz), 6.92 (d, H7, 3.9 Hz), 7.12 (d, $\mathrm{H} 8,3.9 \mathrm{~Hz}), 4.87\left(\mathrm{~s}, \mathrm{CrCOCH}_{3}\right) .4 .81\left(\mathrm{~s}, \mathrm{WCOCH}_{3}\right){ }^{-13} \mathrm{C} \mathrm{NMR}$ $\left(\mathrm{CDCl}_{3}, \mathrm{ppm}\right): \delta 310(\mathrm{Cl}(\mathrm{Cr})), 284\left(\mathrm{Cl}^{\prime}(\mathrm{W})\right), 224\left(\mathrm{Cr}(\mathrm{CO})_{5}\right.$, trans $)$, $216\left(\mathrm{Cr}(\mathrm{CO})_{5}\right.$, cis $), 204\left(\mathrm{~W}(\mathrm{CO})_{5}\right.$, trans $), 197\left(\mathrm{~W}(\mathrm{CO})_{5}\right.$, cis $), 156$ (C2), 142 (C3), 127 (C4), 156, 155 (C5, C6), 112 (C7), 115 (C8), $166(\mathrm{C} 9), 68\left(\mathrm{~W}-\mathrm{OCH} \mathrm{H}_{3}\right), 66\left(\mathrm{Cr}^{-O} \mathrm{CH}_{3}\right)-\mathrm{IR}\left(\right.$ hexane, $\left.\mathrm{cm}^{-1}\right): v_{\mathrm{CO}}=$ 2066, 2056 (m), 1986 (vw), 1957 (s), 1948 (vs), 1950 (vs), 1958 (s).

\section{Synthesis of $\left[(\mathrm{CO})_{5} \mathrm{~W}\{\mathrm{C}(\mathrm{OMe}) \mathrm{Th}-\mathrm{FuC}(\mathrm{OMe})\} \mathrm{Cr}(\mathrm{CO})_{5}\right]$ (18)}

The same procedure described above was followed but tungsten hexacarbonyl was added after the first lithiation instead of chromium hexacarbonyl, which was only added after the second metallation. Other products isolated were $1(5 \%), 2(18 \%)$ and $3(7 \%)$.

\section{Characterization of product}

18. Yield $0.30 \mathrm{~g}(0.40 \mathrm{mmol}, 8 \%)$. Anal. calcd for $\mathrm{C}_{22} \mathrm{H}_{10} \mathrm{O}_{13} \mathrm{SWCr}$ (750.2): C 35.22, H 1.34; Found: C 35.33, H 1.46 MS (EI): $m / z[\mathrm{M}]^{+}$not observed- ${ }^{1} \mathrm{H}$ NMR $\left(\mathrm{CDCl}_{3}, \mathrm{ppm}\right): \delta 8.13$ (d, H3, $4.4 \mathrm{~Hz}), 7.60$ (d, H4, $4.4 \mathrm{~Hz}), 6.92$ (d, H7, $4.4 \mathrm{~Hz}), 6.94$ (d, H8, 4.4, $3.6 \mathrm{~Hz}), 4.80\left(\mathrm{~s}, \mathrm{CrCOCH}_{3}\right), 4.69\left(\mathrm{~s}, \mathrm{WCOCH}_{3}\right) \cdot{ }^{13} \mathrm{C}$ $\mathrm{NMR}\left(\mathrm{CDCl}_{3}, \mathrm{ppm}\right): \delta 291(\mathrm{C} 1(\mathrm{~W})), 311\left(\mathrm{Cl}^{\prime}(\mathrm{Cr})\right), 224\left(\mathrm{Cr}(\mathrm{CO})_{5}\right.$, trans), $217\left(\mathrm{Cr}(\mathrm{CO})_{5}\right.$, cis $), 202\left(\mathrm{~W}(\mathrm{CO})_{5}\right.$, trans $), 197\left(\mathrm{~W}(\mathrm{CO})_{5}\right.$, cis $)$, 158 (C2), 142 (C3), 127 (C4), 156 (C5), 146 (C6), 112 (C7), 112 (C8), $163(\mathrm{C} 9), 69\left(\mathrm{~W}-\mathrm{OCH}_{3}\right), 66\left(\mathrm{Cr}^{-O} \mathrm{OCH}_{3}\right)$ - IR (hexane, $\left.\mathrm{cm}^{-1}\right)$ : $v_{\mathrm{CO}}=2066,2056(\mathrm{~m}), 1986(\mathrm{vw}), 1957$ (s), 1947 (vs).

\section{Synthesis of metal carbene complexes from N-methylthienylpyrrole(HTh-PyrH)}

Synthesis of $\left[\mathbf{C r}(\mathbf{C O})_{5}\{\mathbf{C}(\mathrm{OMe}) \mathbf{T h}-\mathrm{PyrH}\}\right]$ (19). $0.325 \mathrm{~g}$ (2.0 mmol) of N-methyl-2,2'-thienylpyrrole was dissolved in $10 \mathrm{~mL}$ of THF and $1.4 \mathrm{~mL}(2.2 \mathrm{mmol})$ of a $1.60 \mathrm{M}$ solution of $n-\mathrm{BuLi}$ in hexane was added at $0-20{ }^{\circ} \mathrm{C}$ and the reaction was stirred for 30 minutes. $0.45 \mathrm{~g}(2.0 \mathrm{mmol})$ of $\mathrm{Cr}(\mathrm{CO})_{6}$ was added at $-40{ }^{\circ} \mathrm{C}$ in small portions where after the temperature was allowed to rise to room temperature. Stirring was maintained for a further $1.5 \mathrm{~h}$ during which the colour of the reaction mixture changed to redbrown. The solvent was removed under reduced pressure and the residue was dissolved in $20 \mathrm{~mL}$ of dichloromethane and cooled to $-20{ }^{\circ} \mathrm{C}$. A solution of $0.39 \mathrm{~g}(2.0 \mathrm{mmol})$ of triethyloxonium tetrafluoroborate in $10 \mathrm{~mL}$ of dichloromethane was added. An immediate colour change to dark red was observed. The cooling bath was removed and stirring was continued for another hour. The mixture was washed with dichloromethane through a filter containing a silica gel plug. The solvent was removed in vacuo and the residue adsorbed on silica gel and purified on a silica gel column with hexane as eluting agent and increasing the polarity gradually by adding dichloromethane to the eluting agent.

\section{Characterization of product}

19. Yield $0.62 \mathrm{~g}(1.52 \mathrm{mmol}, 76 \%)$ Anal. calcd for $\mathrm{C}_{17} \mathrm{H}_{13} \mathrm{O}_{6} \mathrm{SNCr}$ (411.4): C 49.64, H 3.19, N 3.41; Found: C 49.82, H 3.31, N 3.35 - MS (EI): $m / z 411[\mathrm{M}]^{+}$, stepwise fragmentation of carbonyl ligands, 271 ([M] $\left.\left.{ }^{+}-5 \mathrm{CO}\right)\right)^{-}{ }^{1} \mathrm{H}$ NMR $\left(\mathrm{CDCl}_{3}, \mathrm{ppm}\right)$ : $\delta 8.19$ (d, H3, $4.40 \mathrm{~Hz}), 7.19$ (d, H4, $4.40 \mathrm{~Hz}), 6.61$ (dd, H7, $3.88,1.55 \mathrm{~Hz}$ ), 6.18 (dd, H8, 3.88, $2.58 \mathrm{~Hz}$ ), 6.78 (dd, H9, 2.58, $1.55 \mathrm{~Hz}), 3.83$ (s, NMe), 5.12 (q, $\left.\mathrm{CrCOCH}_{2}-, 6.99 \mathrm{~Hz}\right), 1.64(\mathrm{t}$, $\left.\left.\mathrm{CrCOCH}_{2} \mathrm{CH}_{3}, 6.99 \mathrm{~Hz}\right)-{ }^{13} \mathrm{C} \mathrm{NMR}\left(\mathrm{CDCl}_{3}, \mathrm{ppm}\right): \delta 309(\mathrm{Cl})\right)$, $223\left(\mathrm{Cr}(\mathrm{CO})_{5}\right.$, trans $), 217\left(\mathrm{Cr}(\mathrm{CO})_{5}\right.$, cis $), 151(\mathrm{C} 2), 143(\mathrm{C} 3), 128$ (C4), 146, 127 (C5, C6), 110 (C7), 113 (C8), 125 (C9), 76 (Cr$\left.\mathrm{OCH}_{2}-\right), 36\left(\mathrm{NCH}_{3}\right), 15 \mathrm{CrCOCH}_{2} \mathrm{CH}_{3}$, ) - IR (hexane, $\left.\mathrm{cm}^{-1}\right)$ : $v_{\mathrm{CO}}=2056(\mathrm{~m}), 1980(\mathrm{vw}), 1944(\mathrm{vs}), 1944$.

\section{Synthesis of $\left[\mathrm{W}(\mathrm{CO})_{5}\{\mathrm{C}(\mathrm{OMe}) \mathrm{Th}-\mathrm{PyrH}\}\right]$ (20)}

The same procedure described above was followed but tungsten hexacarbonyl was added after the lithiation instead of chromium hexacarbonyl.

\section{Characterization of product}

20. Yield $0.88 \mathrm{~g}$ (1.62 mmol, 81\%). Anal. calcd for $\mathrm{C}_{17} \mathrm{H}_{13} \mathrm{O}_{6} \mathrm{SNW}$ (543.2): C 37.59, H 2.41, N 2.58; Found: C 37.73, $\mathrm{H} 2.68, \mathrm{~N} 2.40-\mathrm{MS}(\mathrm{EI}): \mathrm{m} / z 543[\mathrm{M}]^{+}$, stepwise fragmentation of carbonyl ligands, 403 ([M] $\left.{ }^{+}-5 \mathrm{CO}\right) .-{ }^{1} \mathrm{H} \mathrm{NMR}\left(\mathrm{CDCl}_{3}, \mathrm{ppm}\right): \delta 8.11$ (d, H3, $4.4 \mathrm{~Hz}), 7.19$ (d, H4, $4.4 \mathrm{~Hz}), 6.64$ (dd, H7, 3.88, $1.81 \mathrm{~Hz}$ ), 6.19 (dd, H8, 3.88, $2.58 \mathrm{~Hz}), 6.60$ (dd, H9, 2.58, $1.81 \mathrm{~Hz}), 3.84$ (s, NMe), 4.95 (q, $\left.\mathrm{WCOCH}_{2-}, 7.24 \mathrm{~Hz}\right), 1.62\left(\mathrm{t}, \mathrm{WCOCH}_{2} \mathrm{CH}_{3}\right.$, $7.24 \mathrm{~Hz}){ }^{-13} \mathrm{C} \mathrm{NMR}\left(\mathrm{CDCl}_{3}, \mathrm{ppm}\right): \delta 285(\mathrm{C} 1), 203\left(\mathrm{~W}(\mathrm{CO})_{5}\right.$, trans), $198\left(\mathrm{~W}(\mathrm{CO})_{5}\right.$, cis $), 154(\mathrm{C} 2), 144$ (C3), 128 (C4), 147, 127 (C5, C6), 109 (C7), 113 (C8), 125 (C9), 78 (W-OCH $2^{-}$), 36 (NMe), $15\left(\mathrm{~W}-\mathrm{OCH}_{2} \mathrm{CH}_{3}\right)$ - IR (hexane, $\left.\mathrm{cm}^{-1}\right): v_{\mathrm{CO}}=2064(\mathrm{~m}), 1977(\mathrm{vw})$, 1941 (vs), 1941.

\section{Reaction of 3, 5 and 15 with 3-hexyne}

\section{General procedure}

$0.45 \mathrm{~mL}$ (4 mmol) 3-hexyne was added to a stirred solution of $1 \mathrm{mmol}$ of the biscarbene metal complex in $10 \mathrm{ml}$ toluene. In the case of 5 only $0.15 \mathrm{mmol}$ was used instead of $1 \mathrm{mmol}$ and other chemicals were reduced accordingly. The reaction mixture was stirred at $80{ }^{\circ} \mathrm{C}$ for 24 hours. The solvent was removed under reduced pressure and the remainder purified by column chromatography on silica gel. Starting with hexane as eluting agent and increasing the polarity gradually by adding dichloromethane the products were isolated. Several organic products were formed 
but no attempt was made to isolate and characterize non-metal containing compounds.

\section{Characterization of products}

21. Anal. calcd for $\mathrm{C}_{24} \mathrm{H}_{20} \mathrm{O}_{8} \mathrm{~S}_{2} \mathrm{Cr}$ :(552.6) C 52.17, H 3.65; Found: C 52.35, H 3.78 MS (EI): $m / z$ [M $]^{+}$not observed- ${ }^{1} \mathrm{H}$ NMR $\left(\mathrm{CDCl}_{3}, \mathrm{ppm}\right): \delta 8.18$ (br, H3), 7.69 (br, H4), 7.40 (s, H7), 4.94 (s, $\mathrm{OH}), 4.81\left(\mathrm{~s}, \mathrm{CrCOCH}_{3}\right), 3.91\left(\mathrm{~s}, \mathrm{BzOCH}_{3}\right), 2.74\left(\mathrm{~s}, \mathrm{BzCH}_{2} \mathrm{CH}_{3}\right)$, $1.23\left(\mathrm{~s}, \mathrm{ArCH}_{2} \mathrm{CH}_{3}\right) .{ }^{13} \mathrm{C} \mathrm{NMR}\left(\mathrm{CDCl}_{3}, \mathrm{ppm}\right): \delta 291(\mathrm{Cl}(\mathrm{W})), 311$ $\left(\mathrm{Cl}^{\prime}(\mathrm{Cr})\right), 224\left(\mathrm{Cr}(\mathrm{CO})_{5}\right.$, trans $), 217\left(\mathrm{Cr}(\mathrm{CO})_{5}\right.$, cis $), 202\left(\mathrm{~W}(\mathrm{CO})_{5}\right.$, trans), 197 (W(CO) $)_{5}$, cis), 158 (C2), 142 (C3), 127 (C4), 156 (C5), 146 (C6), 112 (C7), 112 (C8), 163 (C9), 69 (W-OCH ), 66 (Cr$\mathrm{OCH}_{3}$ ) - IR (hexane, $\mathrm{cm}^{-1}$ ): $v_{\mathrm{CO}}=2066,2056(\mathrm{~m}), 1986(\mathrm{vw}), 1957$ (s), 1947 (vs).

22. Anal. calcd for $\mathrm{C}_{24} \mathrm{H}_{20} \mathrm{O}_{8} \mathrm{~S}_{2} \mathrm{~W}$ (684.4): $\mathrm{C}$ 42.12, $\mathrm{H}$ 2.95; Found: C 42.26, H $3.08 \mathrm{MS}$ (EI): $m / z$ [M] ${ }^{+}$not observed- ${ }^{1} \mathrm{H}$ NMR $\left(\mathrm{CDCl}_{3}, \mathrm{ppm}\right): \delta 8.10$ (br, H3), 7.31 (br, H4), 7.36 (s, H7), 4.93 (s, $\mathrm{OH}), 4.64\left(\mathrm{~s}, \mathrm{WCOCH}_{3}\right), 3.91\left(\mathrm{~s}, \mathrm{BzOCH}_{3}\right), 2.74\left(\mathrm{~s}, \mathrm{BzCH}_{2} \mathrm{CH}_{3}\right)$, $1.24\left(\mathrm{~s}, \mathrm{BzCH}_{2} \mathrm{CH}_{3}\right)$. - IR (hexane, $\left.\mathrm{cm}^{-1}\right): v_{\mathrm{CO}}=2066,2056(\mathrm{~m})$, 1986 (vw), 1957 (s), 1947 (vs).

23. Anal. calcd for $\mathrm{C}_{24} \mathrm{H}_{20} \mathrm{O}_{9} \mathrm{SCr}$ (536.5): C 53.74, $\mathrm{H} 3.76$; Found: C 53.90, H $3.87 \mathrm{MS}(\mathrm{EI}): \mathrm{m} / \mathrm{z}[\mathrm{M}]^{+}$not observed- ${ }^{1} \mathrm{H}$ NMR ( $\left.\mathrm{CDCl}_{3}, \mathrm{ppm}\right): \delta 7.00$ (br, H3), 6.73 (br, H4), 7.86 (s, H7), 4.92 (s, OH), 5.13 (q, $\left.\mathrm{CrCOCH}_{2} \mathrm{CH}_{3}\right), 4.81\left(\mathrm{~s}, \mathrm{CrCOCH}_{2} \mathrm{CH}_{3}\right)$, $3.91\left(\mathrm{~s}, \mathrm{BzOCH}_{3}\right), 2.75\left(\mathrm{~s}, \mathrm{BzCH}_{2} \mathrm{CH}_{3}\right), 1.24\left(\mathrm{~s}, \mathrm{BzCH}_{2} \mathrm{CH}_{3}\right){ }^{13} \mathrm{C}$ $\mathrm{NMR}\left(\mathrm{CDCl}_{3}, \mathrm{ppm}\right): \delta 291(\mathrm{Cl}(\mathrm{W})), 311\left(\mathrm{Cl}^{\prime}(\mathrm{Cr})\right), 224\left(\mathrm{Cr}(\mathrm{CO})_{5}\right.$, trans), $217\left(\mathrm{Cr}(\mathrm{CO})_{5}\right.$, cis $), 202\left(\mathrm{~W}(\mathrm{CO})_{5}\right.$, trans $), 197\left(\mathrm{~W}(\mathrm{CO})_{5}\right.$, cis $)$, 158 (C2), 142 (C3), 127 (C4), 156 (C5), 146 (C6), 112 (C7), 112 (C8), $163(\mathrm{C} 9), 69\left(\mathrm{~W}-\mathrm{OCH} \mathrm{CH}_{3}\right), 66\left(\mathrm{Cr}^{-O} \mathrm{OCH}_{3}\right)$ - IR (hexane, $\left.\mathrm{cm}^{-1}\right)$ : $v_{\mathrm{CO}}=2066,2056(\mathrm{~m}), 1986(\mathrm{vw}), 1957$ (s), 1947 (vs).

\section{Carbene coupling reactions}

\section{General procedure}

The carbene complex $(1 \mathrm{mmol})$ and 0.1 molar equivalents of $\mathrm{Pd}\left(\mathrm{PPh}_{3}\right)_{4}$ were refluxed in $10 \mathrm{~mL}$ of THF for 3 hours. The reaction mixture was monitored by thin layer chromatography to make sure all precursor complexes were consumed before the solvent was removed under reduced pressure. The residue was dissolved in dichloromethane and filtered through a silica gel plug. Thin layer chromatography revealed one major, organic product from the reaction of $\mathbf{1 3}$ and more products for the reaction of 15. Only the main product of each reaction was purified by column chromatography on silica gel and characterized by NMR spectroscopy. Starting with hexane as eluting agent and increasing the polarity gradually by adding dichloromethane to the eluting agent the products were isolated.

\section{Characterization of products}

24. $\mathrm{MS}$ (EI): $m / z 412[\mathrm{M}]^{+}{ }^{1}{ }^{1} \mathrm{H}$ NMR $\left(\mathrm{CDCl}_{3}, \mathrm{ppm}\right): \delta 7.14$ (d, H3, 1.8, $3.9 \mathrm{~Hz}), 7.48$ (d, H4, $3.9 \mathrm{~Hz}), 6.46$ (dd, H7, 3.36, $0.9 \mathrm{~Hz}$ ), 6.39 (dd, H8, 3.36, $1.8 \mathrm{~Hz}), 7.36$ (dd, H9, 1.8, 0.9), 3.87 (q, $\left.\mathrm{OCH}_{2} \mathrm{CH}_{3}, 6.99 \mathrm{~Hz}\right), 1.41\left(\mathrm{t}, \mathrm{OCH}_{2} \mathrm{CH}_{3}, 6.99 \mathrm{~Hz}\right) \cdot{ }^{-13} \mathrm{C} \mathrm{NMR}$ $\left(\mathrm{CDCl}_{3}, \mathrm{ppm}\right): \delta 77(\mathrm{C} 1), 135(\mathrm{C} 2), 126(\mathrm{C} 3), 122,134,150(\mathrm{C} 4-$ C6), 112 (C7), 105 (C8), $142(\mathrm{C} 9), 68\left(\mathrm{OCH}_{2} \mathrm{CH}_{3}\right), 16\left(\mathrm{OCH}_{2} \mathrm{CH}_{3}\right)$.
25. MS (EI):): $m / z 438[\mathrm{M}]^{+}-{ }^{1} \mathrm{H}$ NMR ( $\left.\mathrm{CDCl}_{3}, \mathrm{ppm}\right): \delta 7.22$ (d, H3, 1.8, 3.86 Hz), 6.97 (d, H4, 3.86 Hz), 6.37 (dd, H7, 3.60, $1.78 \mathrm{~Hz}), 6.16$ (dd, H8, 3.60, $2.77 \mathrm{~Hz}), 6.70$ (dd, H9, 2.77, 1.78), 3.92 (q, $\left.\mathrm{OCH}_{2} \mathrm{CH}_{3}, 7.05 \mathrm{~Hz}\right), 1.43\left(\mathrm{t}, \mathrm{OCH}_{2} \mathrm{CH}_{3}, \mathrm{~Hz}\right) \cdot{ }^{-13} \mathrm{C} \mathrm{NMR}$ $\left(\mathrm{CDCl}_{3}, \mathrm{ppm}\right): \delta 77(\mathrm{C} 1), 136(\mathrm{C} 2), 126(\mathrm{C} 3), 125,135,128(\mathrm{C} 4-$ C6), 110 (C7), 109 (C8), 124 (C9), 36 (NMe), $68\left(\mathrm{OCH}_{2} \mathrm{CH}_{3}\right), 16$ $\left(\mathrm{OCH}_{2} \mathrm{CH}_{3}\right)$.

26. $\mathrm{MS}(\mathrm{EI}): m / z 294[\mathrm{M}]^{+}-{ }^{1} \mathrm{H} \mathrm{NMR}\left(\mathrm{CDCl}_{3}, \mathrm{ppm}\right): \delta 7.91$ (d, H3, $3.9 \mathrm{~Hz}), 7.43$ (d, H4, $3.9 \mathrm{~Hz}), 6.56$ (d, H7, 3.6 Hz), 6.89 (d, $\mathrm{H} 8,3.6 \mathrm{~Hz}), 4.34$ (q, $\left.\mathrm{OCH}_{2} \mathrm{CH}_{3}, 7.0 \mathrm{~Hz}\right), 1.45$ (t, $\mathrm{OCH}_{2} \mathrm{CH}_{3}$, $7.0 \mathrm{~Hz})$.

\section{X-Ray structure determination}

The intensity data were collected at $-90^{\circ} \mathrm{C}$ on a Nonius Kappa CCD diffractometer for compounds 12, 14 and 20 using graphitemonochromated Mo-K $\alpha$ radiation. Data were corrected for Lorentz, polarization effects but not for absorption. ${ }^{45}$ The structures were solved by Direct Methods (SHELXS) ${ }^{46}$ and refined by full-matrix least squares techniques against $\mathrm{F}_{\mathrm{o}}{ }^{2}$ (SHELXL-97). ${ }^{47}$ The hydrogen atoms of the structures were included at calculated positions with fixed thermal parameters. All non-hydrogen atoms were refined anisotropically. Ortep-3 for Windows ${ }^{48}$ and POV-Ray for Windows ${ }^{49}$ were used for the structure representations. The molecule of $\mathbf{1 2}$ is symmetrical and lies across a crystallographic inversion centre. Other experimental details are given in Table 3.

\section{Acknowledgements}

This work was supported financially by the University of Pretoria and by the National Research Foundation of South Africa under Grant No's: 2047221(SL).

\section{References}

1 P. Bäuerle, Oligothiophenes in Electronic Materials: The Oligomeric Approach. (Eds. G. Wegner, and K. Müllen), Wiley-VCH, Weinheim, 1998, 105.

2 (a) I. J. S. Fairlamb, Chem. Soc. Rev., 2007, 36, 1036; (b) S. P. Stanforth, Tetrahedron, 1998, 54, 263.

3 (a) T. Tamao, S. Kodama, I. Nakajima, M. Kumada, A. Minto and K. Suzuki, Tetrahedron, 1982, 38, 3347; (b) N. Jayasuriya and J. Kagan, Heterocycles, 1986, 24, 2261; (c) A. Carpita, R. Rossi and C. A. Veracini, Tetrahedron, 1985, 41, 1919.

4 A. Minato, K. Tamao, T. Hayashi, K. Suzuki and M. Kumada, Tetrahedron Lett., 1981, 22, 5319.

5 G. T. Crisp, Synth. Commun., 1989, 19, 307.

6 S. Gronowitz and K. Lawitz, Chem. Scr., 1984, 23, 120.

7 M. D’Auria, A. De Mico, F. D’Onofrio and G. Piancatelli, J. Org. Chem., 1987, 52, 5234.

8 I. V. Seregin and V. Gevorgyan, Chem. Soc. Rev., 2007, 36, 1173.

9 (a) A. R. Katritzky, J. Li and M. F. Gordeev, Synthesis, 1994, 93; (b) F. Lucchesini, Tetrahedron, 1992, 48, 9951.

10 L. Brandsma, S. F. Vasilevsky, and H. D. Verkruijsse, Application of Transition Metal Catalysts in Organic Synthesis, Springer-Verlag, Berlin/Heidelberg, 1998.

11 S. Maiorana, A. Papagni, E. Licandro, A. Persoons, K. Clay, S. Houbrechts and W. Porzio, Gazz. Chim. Ital., 1995, 125, 377.

12 A. O. Patil, A. J. Heeger and F. Wudl, Chem. Rev., 1988, 88, 183.

13 M. Schlosser, Organometallics in Synthesis. A Manual. (M. Schlosser, ed.), Second edition, Wiley, London, 2004, pp 236, 240-241.

14 (a) E. O. Fischer, W. Held, F. R. Kreissl, A. Frank and G. Huttner, Chem. Ber., 1977, 110, 656; (b) J. A. Connor and E. M. Jones, J. Chem. Soc. A, 1971, 1974. 
15 (a) Y. M. Terblans, H. M. Roos and S. Lotz, J. Organomet. Chem., 1998, 566, 133; (b) D. Liles and S. Lotz, Acta Crystallogr., Sect. E: Struct. Rep. Online, 2006, 62, m331.

16 (a) K. H. Dötz, H. Fischer, P. Hofmann, F. R. Kreissl, U. Schubert, and K. Weiss, Transition Metal Carbene Complexes, VCH, Verlag, Weinheim, 1983; (b) T. Barluenga and F. J. Fañanás, Tetrahedron, 2000, 56, 4597; (c) K. H. Dötz, Angew. Chem., Int. Ed. Engl., 1984, 23, 587; (d) A. de Meijere, H. Schimmer and M. Duetsch, Angew. Chem., Int. Ed., 2000, 39, 3964.

17 M. Landman, H. Görls and S. Lotz, J. Organomet. Chem., 2001, 617618, 282.

18 (a) M. Landman, H. Görls and S. Lotz, Eur. J. Inorg. Chem., 2001, 233; (b) S. Lotz, M. Landman, H. Görls, C. Crause, H. Nienaber and A. J. Olivier, Z. Naturforsch., 2007, 62b, 419.

19 K. M. Hossain, T. Kameyama, T. Shibata and K. Takagi, Bull. Chem. Soc. Jpn., 2001, 74, 2415.

20 L. Brandsma, S. F. Vasilevsky, and H. D. Verkruijsse, Application of Transition Metal Catalysis in Organic Synthesis, Springer-Verlag, Berlin/Heidelberg 1998, 15.

21 L. Brandsma, S. F. Vasilevsky, and H. D. Verkruijsse, Application of Transition Metal Catalysis in Organic Synthesis, Springer-Verlag, Berlin/Heidelberg 1998, 264.

22 H. Wynberg, H. J. M. Sinnige and H. M. J. C. Creemers, J. Org. Chem., 1971, 36, 1011.

23 D. J. Chadwick and C. Wilbe, J. Chem. Soc., Perkin Trans. 1, 1977, 887.

24 A. Carpita, R. Rossi and C. A. Veracini, Tetrahedron, 1985, 41, 1919.

25 J. Christoffers and K.-H. Dötz, Organometallics, 1994, 13, 4189.

26 H. G. Raubenheimer, Y. Stander, E. K. Marais, C. Thompson, G. J. Kruger, S. Cronje and M. Deetlefs, J. Organomet. Chem., 1999, 590, 158.

27 Y. M. Terblans and S. Lotz, J. Chem. Soc., Dalton Trans., 1997, 2177.

28 T. Kauffmann and H. Lexy, Chem. Ber., 1981, 114, 3674.

29 A. Aoki, T. Fujimura and E. Nakamura, J. Am. Chem. Soc., 1992, 114, 2985.

30 C. Crause, H. Görls and S. Lotz, Dalton Trans., 2005, 1649.

31 K.-H. Dötz, Angew. Chem., Int. Ed. Engl., 1975, 14, 644.

32 (a) K. H. Dötz and P. Tomuschat, Chem. Soc. Rev., 1999, 28, 187; (b) K. H. Dötz and R. Dietz, Chem. Ber., 1978, 111, 2517; (c) W. D. Wulff, J. S. McCallum and F. A. Kunng, J. Am. Chem. Soc., 1988, 110, 7419; (d) A. Yamashita, A. Toy, W. Watt and C. R. Muchmore, Tetrahedron Lett., 1988, 29, 3403.
33 W. D. Wulff, B. M. Bax, T. A. Brandvold, K. S. Chan, A. M. Gilbert and R. P. Hsung, Organometallics, 1994, 13, 102.

34 (a) N. Hoa Tran Huy and P. Lefloch, J. Organomet. Chem., 1988, 344, 303; (b) R. Neidlin and S. Gürtler, Helv. Chim. Acta, 1994, 77, 2303; (c) P. Tomuschat, L. Kröner, E. Steckhan, M. Nieger and K. H. Dötz, Chem.-Eur. J., 1999, 5, 700.

35 E. O. Fischer, B. Heckl, K. H. Dötz, J. Müller and H. Werner, J. Organomet. Chem., 1968, 16, 29.

36 E. O. Fischer and S. Riedmüller, Chem. Ber., 1974, 107, 915.

37 E. O. Fischer and K. H. Dötz, Chem. Ber., 1972, 105, 3966.

38 (a) M. A. Sierra, M. J. Mancheño, E. Sáez and J. C. del Amo, J. Am. Chem. Soc., 1998, 120, 6812; (b) M. A. Sierra, J. C. del Amo, M. J. Mancheño and M. Gómez-Gallego, J. Am. Chem. Soc., 2001, 123, 851; (c) M. A. Sierra, J. C. del Amo, M. J. Mancheño, M. Gómez-Gallego and M. R. Torres, Chem. Commun., 2002, 1842.

39 M. Landman, H. Görls and S. Lotz, Z. Anorg. Allg. Chem., 2002, 628, 2037.

40 (a) I. Fernández, F. P. Cossio, A. Arrieta, B. Lecea, M. J. Mancheño and M. A. Sierra, Organometallics, 2004, 23, 1065; (b) D. M. Andrada, M. E. Z. Michoff, I. Fernández, A. M. Granados and M. A. Sierra, Organometallics, 2007, 26, 5854.

41 D. I. Bezuidenhout, E. Van der Watt, D. C. Liles, M. Landman and S. Lotz, Organometallics, 2008, 27, 2447.

42 G. H. Spies and R. J. Angelici, Organometallics, 1987, 6, 1897.

43 H. Meerwein, Org. Synth., 1966, 46, 113.

44 L. Brandsma, S. F. Vasilevsky and H. D. Verkruijsse, Application of Transition Metal Catalysis in Organic Synthesis, Springer-Verlag, Berlin/Heidelberg 1998, 4-6.

45 (a) COLLECT, Data Collection Software, Nonius B. V., Netherlands, 1998; (b) Z. Otwinowski and W. Minor, Processing of X-ray Diffraction Data Collected in Oscillation Mode in: Methods in Enzymology, 276, Macromolecular Crystallography, Part A (Eds. C. W. Carter, R. M. Sweet), Academic Press, 1997, 307.

46 G. M. Sheldrick, Acta Crystallogr., Sect. A: Found. Crystallogr., 1990, 46, 467.

47 G. M. Sheldrick, SHELXL-97 (Release 97-2), University of Göttingen, Germany, 1997.

48 L. J. Faruggia, ORTEP-,3 for Windows-a version of ORTEP-III with a graphical user interface (GUI), J. Appl. Crystallogr., 1997, 30, 565.

49 POV-Ray for Windows. (Version 3.6) Persistence of Vision, Raytracer Pty. Ltd., Victoria, Australia. URL: http://www.povray.org; 2004. 